Ecclesia. Studia z Dziejów Wielkopolski t. 12 (2017)

doi: 10.14746/e.2017.12.3

SALEZY BOGUMIŁ TOMCZAK

Klasztor Franciszkanów w Poznaniu

\title{
Mowa przy pożegnaniu Wielebnych OO. Reformatów we Wronkach wygloszona przez księdza Wincentego Kałkowskiego. Reprint źródła i komentarz
}

\section{Wstęp}

W Centralnej Bibliotece Prowincji św. Franciszka z Asyżu Zakonu Braci Mniejszych w Poznaniu przy ul. Garbary 22 znajduje się druk zatytułowany: Mowa przy pożegnaniu Wielebnych OO. Reformatów we Wronkach powiedziana przez X. Katkowskiego, wikaryusza w Ostrorogu. Broszurka liczy 12 stron, formatu $14,5 \times 21,5 \mathrm{~cm}$, wydrukowana nakładem autora w 1875 roku w „Drukiem J.I. Kraszewskiego (Dr. W. Łebiński) w Poznaniu”. Wiele lat temu, w czasie jednej z wizyt $\mathrm{w}$ znanym poznańskim antykwariacie, który mieścił się przy Starym Rynku w Poznaniu, na ów druk natknął się - i oczywiście nabył go - autor niniejszego tekstu. Mowa pożegnalna ks. Wincentego Kałkowskiego jest niezwykłą rzadkością. Dość powiedzieć, że nie odnotował jej Karol Estreicher w swojej Bibliografii polskiej XIX wieku. Nie ma tego druku także w dobrze przecież zaopatrzonej Bibliotece Wydziału Teologicznego Uniwersytetu im. Adama Mickiewicza w Poznaniu i w innych bibliotekach. Druczek zasługuje na uwagę jako ciekawy przyczynek do dziejów kościoła i klasztoru we Wronkach, zakonu franciszkańskiego i samych Wronek, dlatego warto go opublikować w formie reprintu.

\section{Zarys dziejów kościoła i klasztoru we Wronkach}

Kościół i klasztor we Wronkach należy do najstarszych fundacji zakonnych $\mathrm{w}$ archidiecezji poznańskiej. Jego historię można podzielić na dwa okresy: dominikański i franciszkański. 


\section{Okres dominikański}

Dzieje dominikanów wronieckich rozpoczęły się 21 listopada 1279 roku, kiedy książę wielkopolski Przemysł II za namową swego spowiednika Teodoryka, lektora poznańskiego klasztoru, wydał dokument dający braciom zakonu kaznodziejskiego prawo budowy kościoła i klasztoru we Wronkach oraz założenia cmentarza na darowanym przez księcia terenie nad Wartą. W dokumencie wydanym przez kancelarię książęcą mówi się także o specjalnych przywilejach dla zakonu, takich jak prawo do łowienia ryb w Warcie i jeziorze w Rzecinie, o prawie do bezpłatnego korzystania z przemiału zboża w młynie książęcym usytuowanym na przeciwległym brzegu Warty oraz o corocznej dotacji ze skarbca książęcego w wysokości 12 grzywien do czasu ukończenia budowy ${ }^{1}$. Dnia 13 lutego 1280 roku książę Przemysł II wydał kolejny dokument, który zawiera dalsze przywileje dla braci kaznodziejów, mianowicie, do czasu zakończenia budowy murowanego kościoła i klasztoru książę oddał im prawo do wsi Piotrowo, teren pod budowę cegielni, ogród i sad, prawo do eksploatacji żwiru i kamieni na terenach książęcych, prawo do wycinania drzew w lesie książęcym z wyjątkiem tych, na których znajdują się pszczele roje, ponadto zwolnił ich z opłat od wozów i statków na ziemiach książęcych ${ }^{2}$. U podłoża życzliwej postawy księcia wobec dominikanów leżały nie tylko względy religijne, ale także polityczne. Połączenie konwentów nadmorskich z pozostałymi klasztorami prowincji miało służyć umocnieniu władzy księcia na tych terenach ${ }^{3}$.

Budowa murowanego kościoła i klasztoru we Wronkach rozpoczęła się rok po wydaniu wspomnianego dokumentu księcia Przemysła II. Nie wiadomo, kiedy została zakończona, nie dysponujemy żadnymi informacjami na temat pierwotnego wyglądu i kształtu kościoła i klasztoru dominikanów wronieckich. W 1603 roku zespół kościelno-klasztorny mocno podupadł. Nowe budynki wzniesiono w trzecim ćwierćwieczu XVII wieku według planów architekta Krzysztofa Bonadury Starszego, budowniczego wielu kościołów w Wielkopolsce. Fundatorem był kasztelan kaliski Jan Korzbok Łącki. Kościół pw. Zwiastowania NMP został zbudowany w stylu barokowym, na planie krzyża, posiadał prostokątny, jednonawowy korpus, do którego przylegał wydłużony, wieloprzęsłowy, sklepiony chór ${ }^{4}$. Do połowy XIX wieku znajdo-

${ }^{1}$ Kodeks Dyplomatyczny Wielkopolski, Poznań 1877, t. 1, nr 489; J. Wiesiołowski, Dominikanie w miastach wielkopolskich $w$ okresie średniowiecza, [w:] Studia nad historia dominikanów w Polsce 1222-1972, t. 1, Warszawa 1975, s. 204.

${ }^{2}$ Kodeks Dyplomatyczny Wielkopolski, dz. cyt., nr 493.

${ }^{3}$ J. Wiesiołowski, Dominikanie w miastach wielkopolskich, dz. cyt., s. 204.

${ }^{4}$ Katalog zabytków sztuki w Polsce, t. V, z. 23, Powiat szamotulski, opr. R. i T. Juraszowie, red. T. Ruszczyńska i A. Sławska, Warszawa 1966, s. 35-36; C. Grot, Wronki. Z dziejów miasta od czasów najdawniejszych do 1945 roku, Wronki 1987, s. 26. 
wał się w jego wnętrzu nagrobek fundatora, który zmarł we Wronkach w 1666 roku i został pochowany w podziemiach kościoła klasztornego, a ściślej mówiąc pod kaplicą Matki Bożej Różańcowej. Nagrobek wystawił syn fundatora $^{5}$, również Jan Korzbok Łącki i zasługi ojca uwiecznił napisem w języku łacińskim, który za C. Grotem podajemy w języku polskim:

Wstrzymaj krok przechodniu i wpatrz się w zwierciadło cnót, jakim był ongiś bardzo sławny Jan Korzbok Łącki, starosta nakielski i kapitan wojsk Królestwa Polskiego. Pochodził on z bardzo starej rycerskiej rodziny Kórzboków, która przed 300 laty przeniosła się ze Śląska do Polski. Od młodości swej poświęcił się służbie wojskowej i 40 lat swego życia spędził na nieustannych wojnach. Za czasów Władysława IV walczył z Moskalami pod Smoleńskiem i z Turkami pod Chocimem. Potem z Kazimierzem III królem polskim brał udział w bitwie z Tatarami i Kozakami pod Beresteczkiem. Potem jeszcze bił się z Moskalami, Węgrami i Szwedami. Odznaczał się roztropnością w udzielaniu rad w zakresie wojskowości i zawsze pomyślnie wykonywał powierzone mu zadania. $\mathrm{Z}$ tego też powodu królowie bardzo go lubili. Wreszcie jako starzec 75-letni tutaj w roku 1666 zakończył swe życie. Jemu to jedyny, przy życiu pozostały syn jego Jan Korzbok zrodzony z Elżbiety Grudzińskiej, w tym czasie podkomorzy wschowski, a potem kasztelan kaliski, z synowskiej miłości i za radą swego stryja Aleksandra Korzboka, kasztelana krzywińskiego, gdy z wyprawy wiedeńskiej wraz z Janem III królem polskim z Węgier przez Kraków wracał, ten pomnik tamże polecił wykonać i tu na grobie swego ojca na pamiątkę położył $\mathfrak{l}^{6}$.

Klasztor wroniecki był jednym ze słabszych ogniw w łańcuchu konwentów dominikańskich w Wielkopolsce zarówno pod względem materialnym, jak i personalnym. Dominikanie wronieccy nie mogli znaleźć w mieście wystarczających środków na utrzymanie klasztoru, w którym mieszkało średnio 12 zakonników ${ }^{7}$. W połowie XVI wieku klasztor wroniecki został „afiliowany dla ubóstwa do konwentu poznańskiego"8.

Dominikanie wronieccy pielęgnowali w swoim kościele tradycyjne nabożeństwa, codziennie sprawowali uroczystą Eucharystię, zasiadali w konfesjonale, a wierni swemu charyzmatowi, kładli szczególny nacisk na głoszenie słowa Bożego na wysokim poziomie, równocześnie wypowiadanego w zrozumiałym dla mas języku. Nic więc dziwnego, że przyciągały one do wronieckiego kościoła klasztornego tłumy ludzi z Wronek oraz bliższej i dalszej

5 J. Łukaszewicz, Krótki opis historyczny kościołów parochialnych ... w dawnej diecezji poznańskiej, t. II, Poznań 1858, s. 407-408.

${ }^{6}$ C. Grot, Wronki, dz. cyt., s. 28.

${ }^{7}$ J. Wiesiołowski, Dominikanie w miastach wielkopolskich, dz. cyt., s. 215.

${ }^{8}$ S. Kozierowski, Szematyzm historyczny ustrojów parafialnych dzisiejszej archidiecezji poznańskiej, Poznań 1935, s. 448-449. 
okolicy. Stało się to zarzewiem konfliktu z miejscowym plebanem Andrzejem Pawko, pochodzącym z wpływowej poznańskiej rodziny. Wystąpił on do sądu przeciwko przeorowi Marcinowi z zarzutem, że przez przyciąganie mieszczan wronieckich kazaniami do kościoła klasztornego powoduje zakłócenia w działalności kościoła parafialnego. Oficjał poznański wydał wyrok, nakazując, że dominikanie non debent ultra et diucius predicare nisi campanum [...] in ecclesia ipsa parochiali in Wronky ad processiones, missas aut predicationes solitas pulsum audiverint mox populum ad ipsam ecclesiam parochialem remitte debent pro audiendum divinis $[. . .]^{9}$. Przy kościele działało kilka bractw religijnych i Trzeci Zakon Dominikański. Stawiały one sobie nie tylko cele religijne, ale również społeczne, takie jak opieka nad chorymi i ubogimi.

W dziejach dominikanów wronieckich nie brakowało dramatycznych momentów, takich jak grabieże, spustoszenia, wojny. W 1316 roku margrabia brandenburski Waldemar najechał Wronki i spowodował wiele szkód, a w 1383 roku miasto ucierpiało w czasie wojny bratobójczej Grzymalitów z Nałęczami. Nieszczęścia związane z tymi najazdami nie ominęły klasztoru dominikanów ${ }^{10}$. Z protokołu powizytacyjnego dowiadujemy się, że w 1603 roku kościół dominikański legł w gruzach, a mienie zakonników dostało się w obce ręce. Zakonnicy przenieśli się do Poznania. Do Wronek wrócili w 1618 roku $^{11}$. W czasie potopu szwedzkiego w 1657 roku Wronki spłonęły prawie doszczętnie. Ucierpiał także kościół i klasztor braci zakonu kaznodziejskiego ${ }^{12}$.

Najbardziej dramatyczny okazał się rok 1835, kiedy rząd pruski zniósł wszystkie klasztory, w tym także wroniecki. Kasata klasztorów była pochodną wrogiej polityki państwa pruskiego wobec Kościoła katolickiego postrzeganego jako ostoja polskości. Proces likwidacji życia zakonnego w zaborze pruskim rozpoczął się w 1810 roku, a zakończył w 1840 roku i przebiegał w kilku etapach. Najpierw wydano edykt, na mocy którego uległy likwidacji dobra kościelne, w tym także klasztorne, następnie zakazano przyjmowania nowicjuszów, na koniec zamykano poszczególne klasztory, w miarę jak wymierali zakonnicy.

\section{Walka o uratowanie kościoła i klasztoru wronieckiego}

Po kasacie klasztoru dominikanów wronieckich wyposażenie kościoła klasztornego w znacznej części przeniesiono do remontowanej fary, zaś budynki wraz z ogrodem i ziemią przekazano szkolnemu towarzystwu katolic-

\footnotetext{
${ }^{9}$ J. Wiesiołowski, Dominikanie w miastach wielkopolskich, dz. cyt., s. 222-223.

${ }^{10}$ Kodeks Dyplomatyczny Wielkopolski, t. III, nr 243.

${ }^{11}$ C. Grot, Wronki, dz. cyt., s. 47-48.

${ }^{12}$ Tamże, s. 28.
} 
kiemu i szkole ewangelickiej z zaleceniem rozebrania kościoła i klasztoru, a $\mathrm{z}$ materiałów w ten sposób uzyskanych miano wybudować nową szkołę. Ekspert budowlany odradzał rozbiórkę obiektu, ponieważ cegła i wapno były tak skamieniałe, że przy rozbiórce mogłyby się całkowicie rozpaść. W tej sytuacji wysunięto propozycję przebudowy kościoła na szkołę ${ }^{13}$. Ten plan jednak upadł. Wówczas postanowiono kościół wraz z klasztorem sprzedać na licytacji, a pieniądze uzyskane ze sprzedaży przeznaczyć na nową szkołę. Licytacja odbyła się 3 czerwca 1851 roku. Nabywcą został proboszcz wroniecki ks. Grzywieński. Jednak władze pruskie nie zatwierdziły kontraktu kupna i wyznaczyły nowy termin licytacji na 15 grudnia 1852 roku. W 1854 roku zawiązał się w Poznaniu Komitet obywatelski składający się z osób duchownych i świeckich, który wyznaczył sobie jako główny cel wykupienie na drodze publicznej licytacji podominikańskiego kościoła klasztornego we Wronkach, jego odnowienie i przywrócenie w nim kultu Bożego. W skład Komitetu weszli dwaj znani kapłani społecznicy poznańscy: ks. Jan Nepomucen Jabczyński ${ }^{14}$ i ks. Franciszek Bażyński ${ }^{15}$ oraz J. Mycielski i ks. Ignacy Stamm, ostatni dominikanin wroniecki. W latach 1854-1868 Komitet wydał trzy odezwy skierowane do duchowieństwa i społeczeństwa katolickiego, zachęcające do składania ofiar na wykupienie i odnowienie kościoła. Do dnia 22 lipca 1861 roku, oprócz drewna i kilku tysięcy cegieł, zebrano 2305 talarów $^{16}$. Z tej sumy 1080 talarów wydano na wykupienie kościoła na drugiej licytacji, a resztę przeznaczono na odnowienie obiektu. Wykonano wówczas następujące prace: wymieniono lub wzmocniono wiązania dachu, zbudowano nową wieżyczkę na dachu kościoła zwieńczoną nowym żelaznym krzyżem, przełożono dach na kościele i zakrystii, naprawiono uszkodzone w kilku miejscach sklepienie kościoła, który także wymalowano, została rozebrana stara kruchta i na nowo wybudowana, oszklono wszystkie okna, wprawiono nowe drzwi do kościoła,

${ }^{13}$ P. Nowak, Dzieje parafii św. Katarzyny Aleksandryjskiej we Wronkach, Poznań 2011, s. 66.

${ }^{14}$ Jan Nepomucen Jabczyński, ur. 1799 w Dolsku. Teologię studiował we Wrocławiu i tam też przyjął święcenia kapłańskie. Był wikarym w Pępowie, Poznaniu i Grodzisku, proboszczem parafii św. Marcina w Poznaniu i w Wirach, kanonikiem katedralnym i wikariuszem generalnym archidiecezji poznańskiej. Założył i redagował „Archiwum Teologiczne”, „Gazetę Kościelną” i „Tygodnik Kościelny”. Zapoczątkował wydawanie źródeł do dziejów ustawodawstwa kościelnego w Polsce. Zmarł w Poznaniu w 1869. Wielkopolski Słownik Biograficzny, Poznań 1981, s. 268.

15 Franciszek Bażyński, ur. 1801 w Poznaniu, działacz polityczny i oświatowy, teologię studiował we Wrocławiu i tam też w 1824 przyjął święcenia kapłańskie. Był wikarym w parafii św. Wojciecha w Poznaniu, proboszczem w Ceradzu Kościelnym, Niepruszewie, Lwówku i św. Wojciecha w Poznaniu. Swoją działalność polityczną i społeczną przypłacił więzieniem w Berlinie i twierdzą w Magdeburgu. Zwolniony dzięki amnestii. W Niepruszewie założył czytelnię, we Lwówku Towarzystwo Wstrzemięźliwości, był posłem na sejm z powiatu bukowskiego. W 1863 założył w Poznaniu Wydawnictwo Dobrych i Tanich Książek. Zmarł w Poznaniu w 1876. Wielkopolski stownik biograficzny, dz. cyt., s. 42-43.

${ }^{16}$ „Tygodnik Katolicki” (Grodzisk), nr 36 (1868), s. 380. 


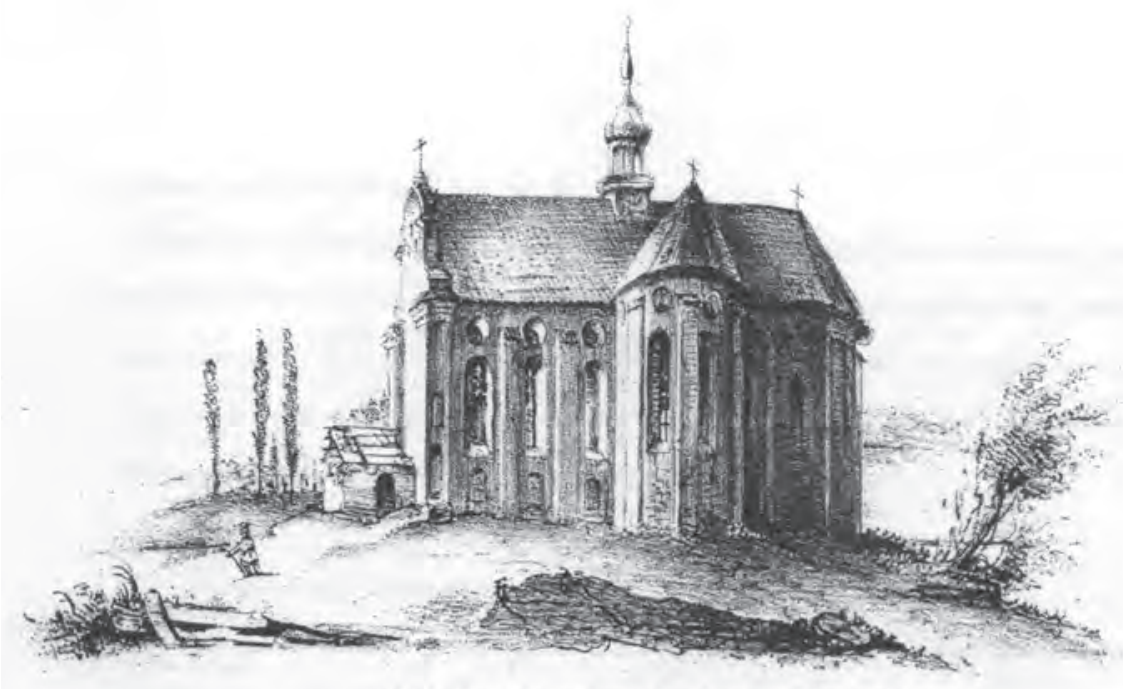

Widok Kościola podominikańskiego w Wronkach

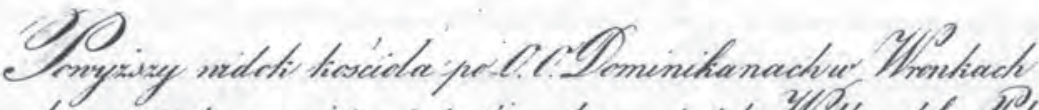

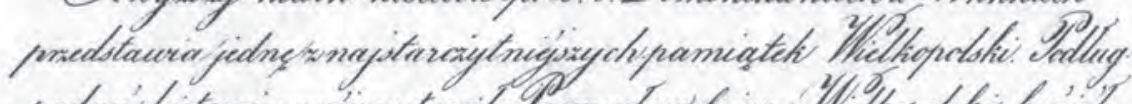

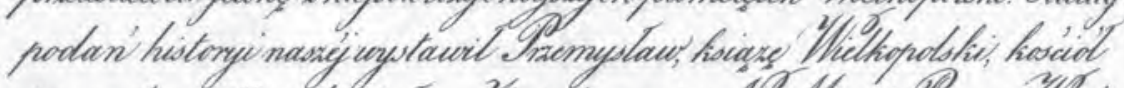

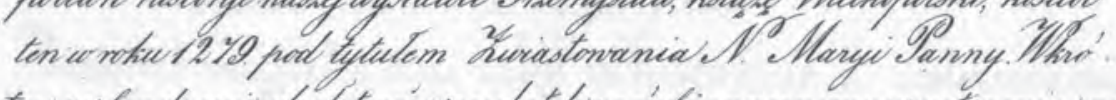

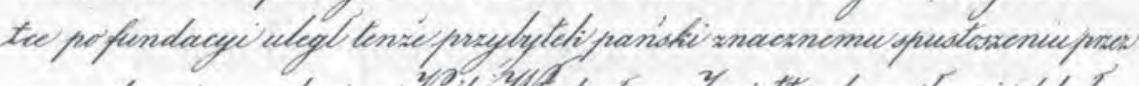

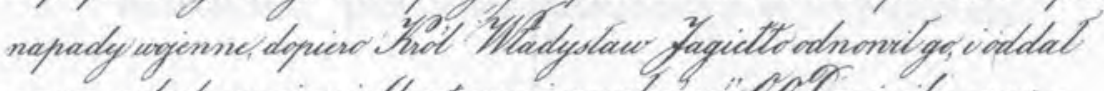

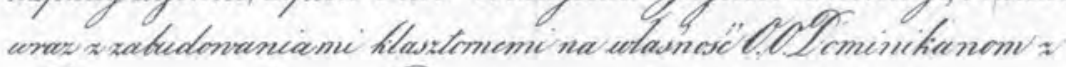

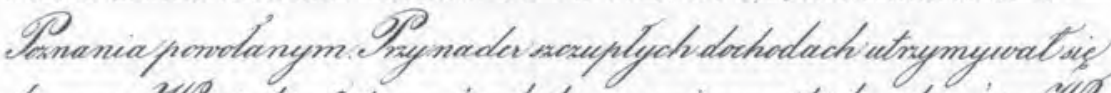

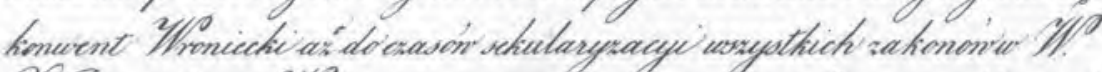

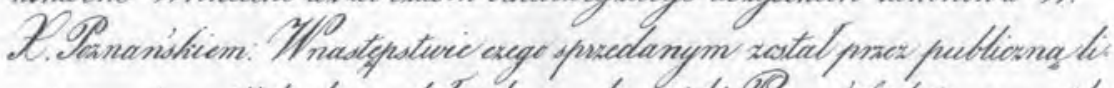

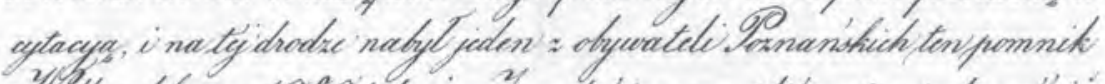

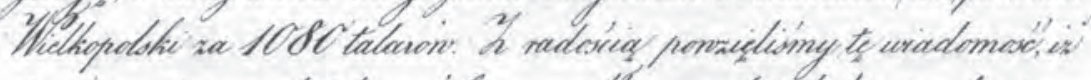

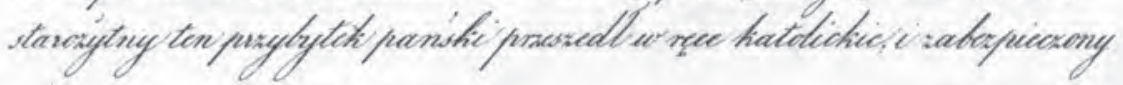




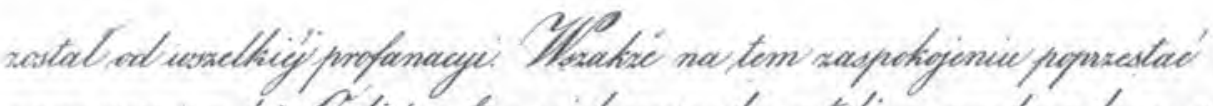

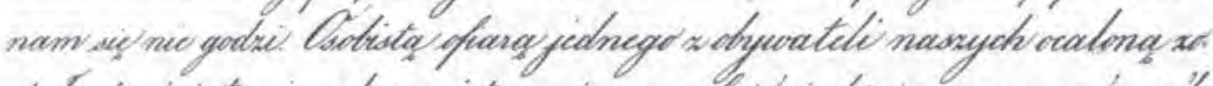

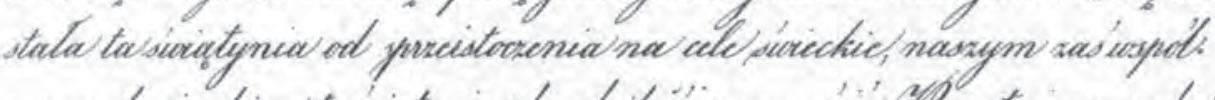

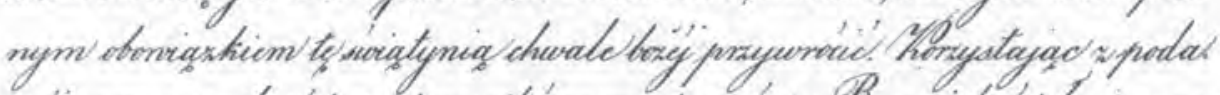

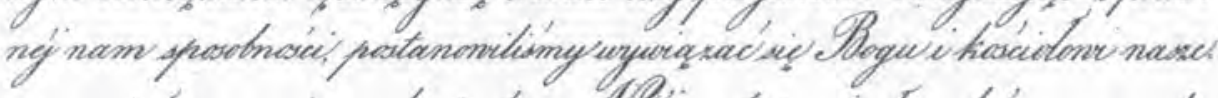

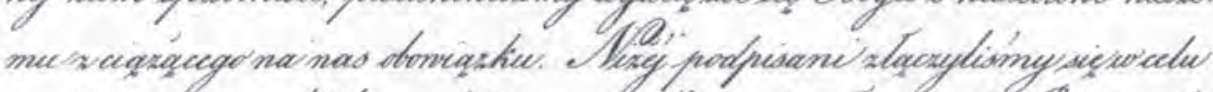

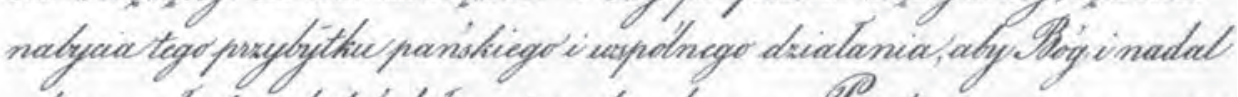

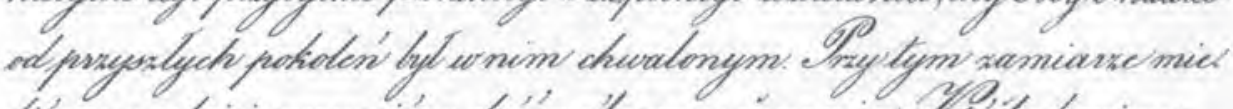

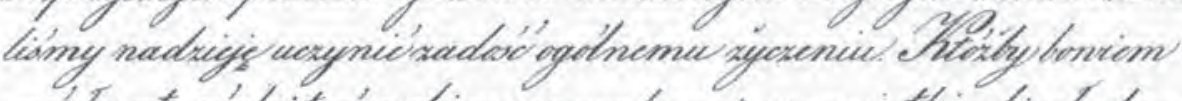

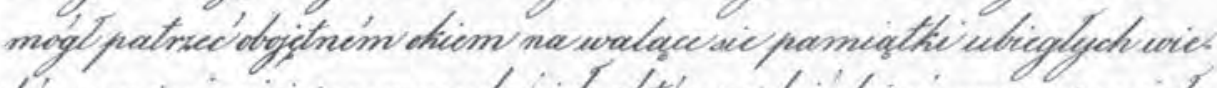

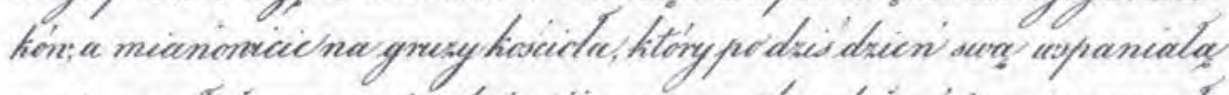

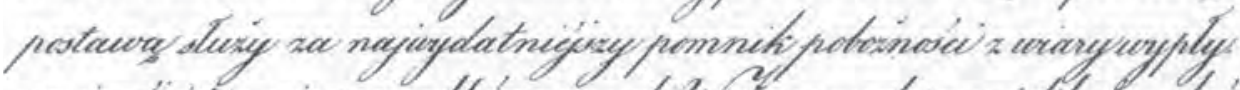

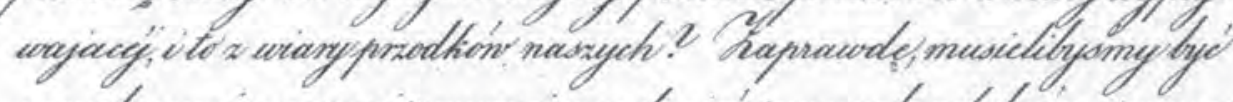

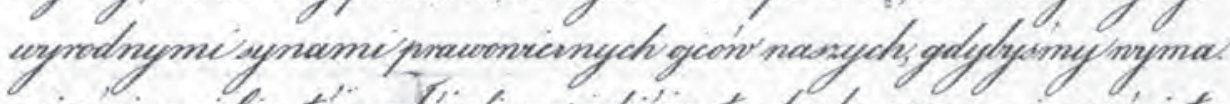

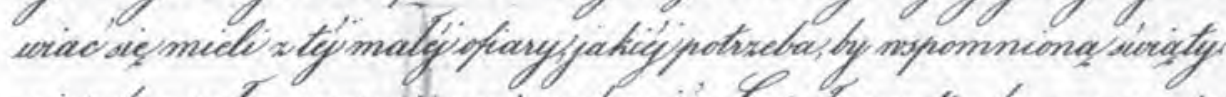

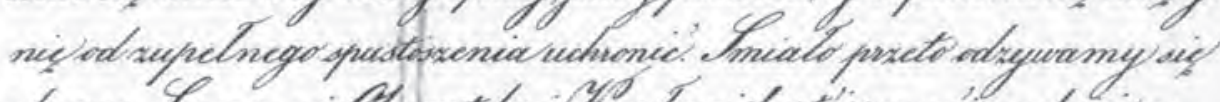

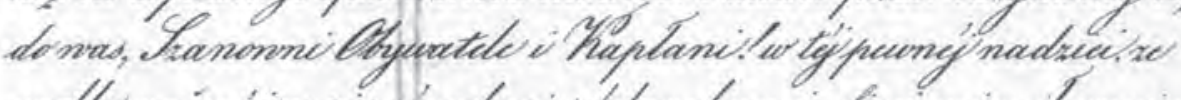

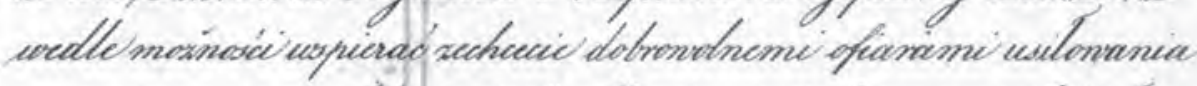

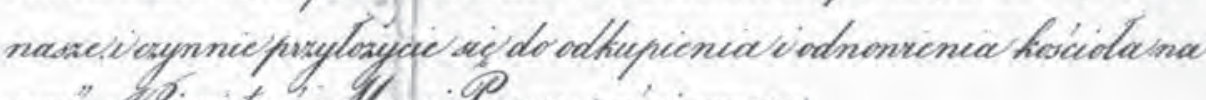

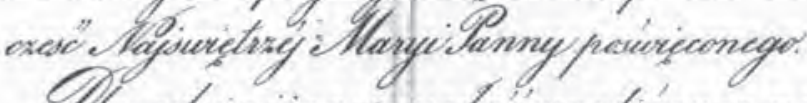

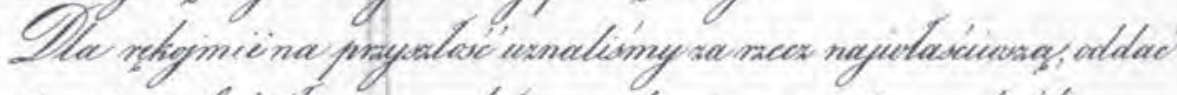
potom tenie frosid uras a nateracym do nicgo quentom w durch morgach,

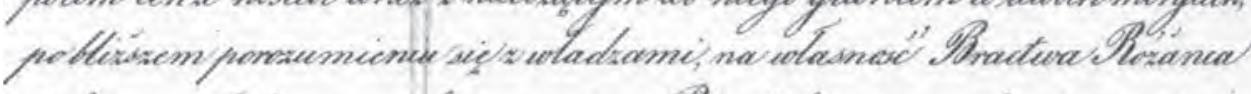

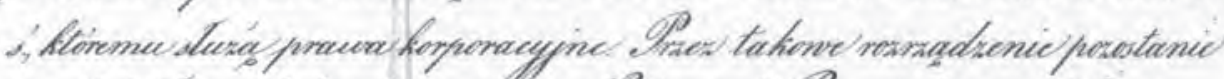

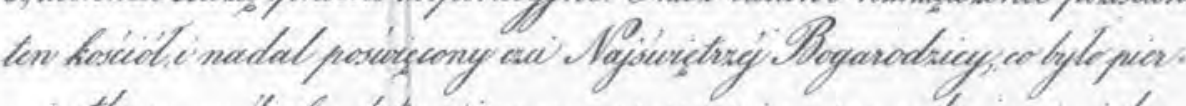

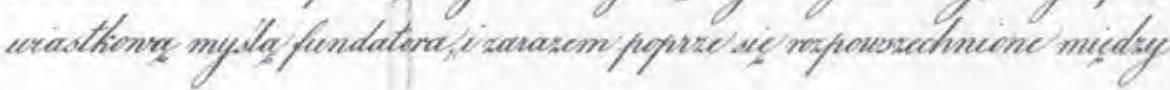


naminatoriéstuo Resaneals.

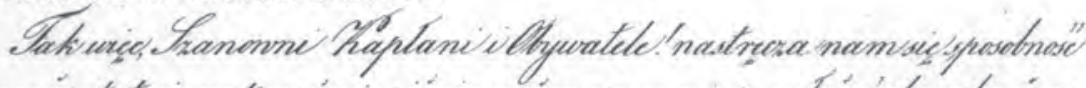

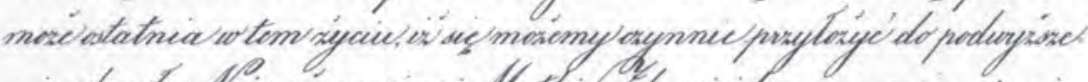

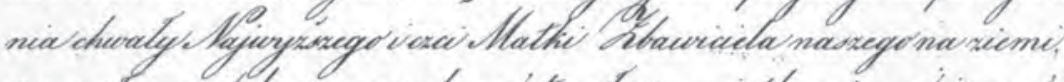

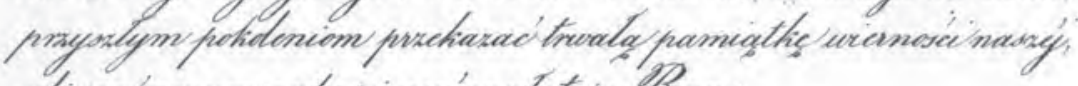

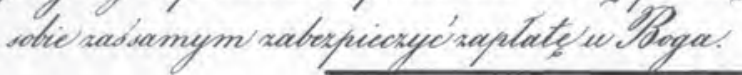

Preaylayiacte odesure na rue

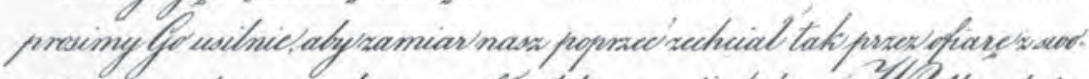

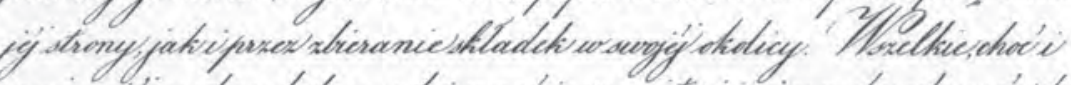

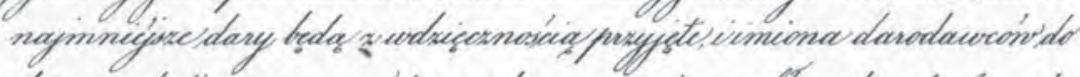

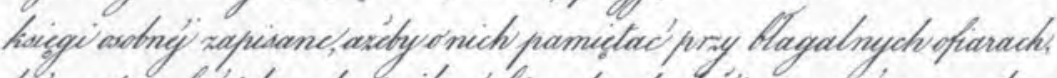

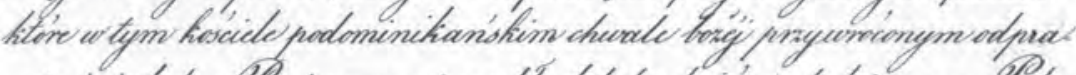

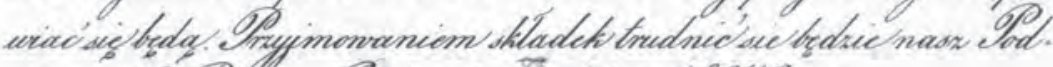

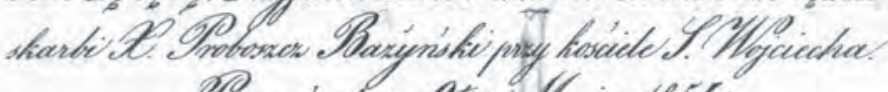
Oonan', dnia Itige Saja 1854

\section{Tomitet, majacy na celm offmpiemis is restamracya hosciola poosominiliantisiego w Wrontiach.}

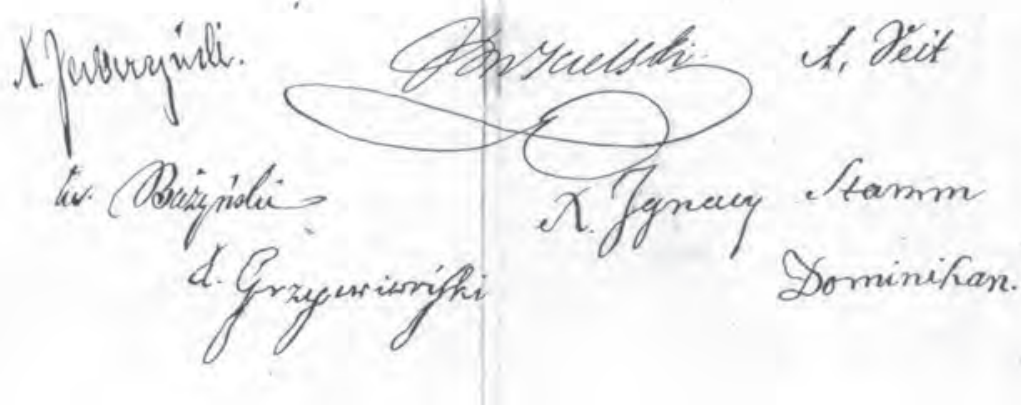


kruchty i zakrystii. Wszelako do całkowitego ukończenia remontu pozostało jeszcze otynkowanie bryły kościoła, odnowienie ołtarzy, namalowanie do nich nowych obrazów, przełożenie posadzki, nowe ławki i konfesjonały, wyposażenie zakrystii w sprzęt potrzebny do sprawowania kultu Bożego i wreszcie budowa nowego klasztoru przynajmniej dla 12 zakonników i jego ogrodzenie. Dwukrotnie, 11 sierpnia 1858 i 22 lipca 1863 roku Komitet zdał sprawozdanie finansowe z wykonanych prac remontowych ks. arcybiskupowi gnieźnieńskiemu i poznańskiemu Leonowi Przyłuskiemu ${ }^{17}$, który to sprawozdanie nie tylko przyjął, ale wyraził Komitetowi swoje podziękowanie i najwyższe uznanie.

Komitet obywatelski długo starał się o to, aby uratowany zabytek trafił w dobre i pewne ręce. W końcu arcybiskup gnieźnieński i poznański Mieczysław Halka Ledóchowski ${ }^{18}$, następca L. Przyłuskiego, przyjął obiekt na swoją i swoich następców własność i następnie przekazał go franciszkanom/reformatom z niedawno utworzonej Prowincji Niepokalanego Poczęcia NMP ${ }^{19}$. Do powstania tej prowincji przyczynił się w sposób wydatny abp L. Przyłuski ${ }^{20}$.

\section{Franciszkanie we Wronkach}

Rok 1868 rozpoczyna nowy okres w dziejach podominikańskiego kościoła pw. Zwiastowania NMP we Wronkach. Uroczyste wprowadzenie zakonników do odnowionego kościoła miało miejsce w niedzielę 25 października tegoż roku. Już jednak w sobotę przybył do miasteczka biskup sufragan gnieźnień-

${ }^{17}$ Leon Przyłuski, ur. 1789, arcybiskup metropolita gnieźnieński i poznański, prymas Polski w latach 1844-1865. Gorliwy pasterz, dbał o poziom naukowy w seminarium duchownym, za postawę patriotyczną rząd pruski dążył do odwołania go z urzędu i deportacji do Rzymu. Zm. w 1865. P. Nitecki, Biskupi Kościoła w Polsce. Stownik biograficzny, Warszawa 1992, s. 173.

${ }^{18}$ Mieczysław Halka Ledóchowski, ur. 1822. Pracował w dyplomacji watykańskiej w Hiszpanii, Portugalii i Kolumbii, nuncjusz apostolski w Brukseli, arcybiskup metropolita gnieźnieński i poznański, prymas Polski, kardynał, uczestniczył w Soborze Watykańskim I, w okresie Kulturkampfu bronił niezależności Kościoła i języka polskiego wobec władz pruskich, uwięziony w Ostrowie Wielkopolskim, został 15 marca 1875 przez papieża Piusa IX kreowany kardynałem-prezbiterem, po uwolnieniu z więzienia (1876) udał się do Rzymu i 2 lutego 1886 zrezygnował z godności arcybiskupa gnieźnieńskiego i poznańskiego, a następnie został prefektem Kongregacji Rozkrzewiania Wiary. Zm. 1902. P. Nitecki, Biskupi Kościoła w Polsce, dz. cyt., s. 120.

${ }^{19}$ Król pruski w krótkich odstępach czasu ogłosił dwie konstytucje, pierwszą 5 XII 1848 i drugą 31 I 1850, które były zapowiedzią łagodniejszego kursu w stosunku do Kościoła. Wyrazem tego był artykuł 11 konstytucji grudniowej, gwarantujący obywatelom całkowitą wolność wyznania. Normalizacja stosunków kościelnych opartych na bazie konstytucji zakładała m.in. przywrócenie przynajmniej niektórych zakonów, zwłaszcza najbardziej przydatnych w duszpasterstwie. Na tej podstawie w 1855 powstała na ziemiach polskich nowa, piąta z kolei, prowincja zakonna franciszkanów/reformatów. W związku z ogłoszonym rok wcześniej dogmatem maryjnym nadano jej tytuł „Niepokalanego Poczęcia NMP” z dodatkiem „w Prusach Zachodnich i Wielkim Księstwie Poznańskim”.

${ }^{20}$ B.S. Tomczak, Arcybiskup Leon Przyluski i odrodzenie franciszkanów-reformatów w Wielkim Księstwie Poznańskim, „Poznańskie Studia Teologiczne”, 2 (1978), s. 305-318. 
ski Józef Cybichowski ${ }^{21}$, aby przewodniczyć uroczystościom. Przed dworcem kolejowym na powitanie biskupa zgromadziło się kilka tysięcy wiernych. Ulicami miasta przystrojonymi kwiatami, zielenią i kolorowymi lampionami przewieziono biskupa powozem przed figurę stojącą na skraju miasta, gdzie oczekiwał na niego miejscowy proboszcz, ks. Szramkowski w otoczeniu zakonników, przedstawicieli bractw i cechów z zapalonymi świecami i pochodniami. Po przemówieniu powitalnym proboszcza ruszył pochód z pieśnią na ustach Kto się w opiekę oddat Najwyższemu. Na trasie pochodu wszystkie okna katolików były oświetlone. Po przybyciu do kościoła farnego i krótkiej adoracji Najświętszego Sakramentu przemówił ks. Biskup, objaśniając cel swego przybycia do Wronek.

Nazajutrz, w niedzielę, o godz. 8, ks. Franciszek Bażyński, proboszcz parafii św. Wojciecha w Poznaniu i syndyk apostolski ${ }^{22}$ klasztoru wronieckiego z upoważnienia władz kościelnych dokonał poświęcenia kościoła i obrazów umieszczonych w ołtarzach głównym i bocznych. Po godz. 9 z kościoła parafialnego wyruszyła procesja eucharystyczna do kościoła klasztornego. Prowadził ją ks. F. Bażyński. Najświętszy Sakrament niesiono w monstrancji, którą ofiarowała radczyni L. Kramarkiewiczowa. Punktem kulminacyjnym uroczystości była msza św. pontyfikalna, którą w kościele klasztornym odprawił ks. biskup J. Cybichowski. Kielich mszalny użyty w czasie tej mszy św., jak również puszka na komunikanty, były darem małżeństwa Wiktorii i Jana Rymarkiewiczów ${ }^{23} \mathrm{z}$ Poznania. Informują o tym odpowiednie napisy umieszczone na wspomnianych naczyniach liturgicznych. Po mszy św. biskup poświęcił kamień węgielny pod budujący się klasztor, którego część fundamentów

${ }^{21}$ Józef Cybichowski, ur. 1828. Studiował w Poznaniu, Bonn i Monachium. Święcenia kapłańskie otrzymał w Gnieźnie w 1852. Był wikarym w parafii katedralnej, prefektem w Wałczu, profesorem seminarium duchownego w Poznaniu, proboszczem w Chodzieży, rektorem seminarium duchownego w Gnieźnie, kanonikiem katedralnym, od 1867 biskup sufragan gnieźnieński, w czasie Kulturkampfu wydalony z diecezji i więziony (1875-1876). Biblista i przyrodnik. Zm. 1887. P. Nitecki, Biskupi Kościoła w Polsce, dz. cyt., s. 41.

${ }^{22} \mathrm{U}$ franciszkanów funkcję syndyka apostolskiego pełniła osoba świecka, niekiedy kapłan albo tercjarz, godna zaufania, wyznaczona przez przełożonych zakonu w imieniu Stolicy Apostolskiej. Wprowadził tę funkcję papież Innocenty IV brewem Quanto studiosius z 1247 (Bullarium Franciscanum I 487-488), a uprawnienia dokładniej określił pap. Marcin IV bullą Exultantes in Domino z 1283 (Bullarium Franciscanum III 501-502); do zadań syndyka apostolskiego należała administracja dóbr używanych przez zakon, także pieniędzy, zawieranie kontraktów. M. Daniluk, K. Klausa, Podręczna encyklopedia instytutów życia konsekrowanego. Pojęcia, terminy, instytucje, dokumenty, czasopisma, sigla, Lublin 1994, s. 262-263.

${ }^{23}$ Jan Rymarkiewicz, ur. 1811, nauczyciel, działacz kulturalny, publicysta, badacz literatury, w latach 1845-1846 redagował „Gazetę Wielkiego Księstwa Poznańskiego”, współpracował m.in. z „Tygodnikiem Literackim”, „Orędownikiem Naukowym” i „Rokiem”. Był autorem kilku podręczników dla szkół średnich. Żonaty był z Wiktorią Ziołecką. Małżeństwo było bezdzietne. Zm. w Poznaniu w 1889. Wielkopolski słownik biograficzny, dz. cyt., s. 639. 
już położono. W uroczystości, oprócz kilku tysięcy wiernych, wzięło udział 17 kapłanów diecezjalnych i 15 zakonnych $^{24}$.

Do najpilniejszych zadań, jakie stanęły przed franciszkanami po przybyciu do Wronek, należała budowa nowego klasztoru, w którym miało się znaleźć mieszkanie dla 12 zakonników, a w przyszłości zamierzali urządzić w nim zakonne studium teologiczne dla kształcenia przyszłych kapłanów. Ofiary na budowę zbierano w Wielkopolsce i na Pomorzu. Do czasu zakończenia budowy klasztoru zakonnicy mieszkali w domu przy ul. Klasztornej nr 6. Pracami budowlanymi kierował o. Urban Raszkiewicz, pierwszy gwardian wroniecki. Do nowego, jeszcze niewykończonego klasztoru bracia wprowadzili się w 1870 roku. Prace budowlane zakończono definitywnie w $1875 \mathrm{roku}^{25}$.

Jakby na ironię losu zakończenie budowy klasztoru zbiegło się Kulturkampfem, czyli nową falą prześladowania Kościoła i polskości. Ostrze nienawiści, podobnie jak to było w przeszłości, zostało wymierzone w zakony. Klasztor wroniecki został więc zamknięty, a zakonnicy, zaledwie po siedmiu latach obecności w miasteczku, musieli je opuścić. W klasztorze pozostał tylko o. Władysław Mulzoff i schorowany brat Józef Igłowski.

Ojciec Władysław był gorliwym duszpasterzem, rozwijał apostolat trzeźwościowy - za jego czasów przy kościele działało Bractwo Wstrzemięźliwości - w zakrystii zachował się obraz bracki, na którym widnieje napis: „Bractwo Wstrzemięźliwości. Klasztor OO. Reformatów, Wronki 1887”. Postarał się o wymurowanie gzymsu w kościele, odrestaurował elewację kościoła, we wnękach umieścił osiem figur, przełożył dach i wymalował ściany. Ponadto jego staraniem wystawiono solidny mur odgradzający teren klasztorny od strony ul. Obrzyckiej. Zmarł 27 lipca 1890 roku i został pochowany na miejscowym cmentarzu parafialnym ${ }^{26}$. Po śmierci o. Władysława rezydentem przy kościele wronieckim był o. Odoryk Smulski, a po nim o. Berard Stawowy. W latach 1909 przebywał we Wronkach o. Euzebiusz Stateczny ${ }^{27}$, a od 1910-1913 o. Antoni Galikowski ${ }^{28}$.

${ }^{24}$ „Tygodnik Katolicki” (Grodzisk), nr 45 (1868), s. 484-485.

${ }^{25}$ S. Tomczak, Dzieje kościoła i klasztoru franciszkanów we Wronkach, „Wronieckie Sprawy”, R. II, nr 8 (11), listopad 1991, s. 2.

${ }^{26}$ W. Piechota, F. Czoska, Zarys dziejów kościoła pod wezwaniem Zwiastowania N.P. Maryi we Wronkach, Wronki 1979, s. 19-21 (maszynopis w posiadaniu Centralnej Biblioteki Prowincji św. Franciszka z Asyżu w Poznaniu, sygn. 262 III).

${ }^{27}$ Euzebiusz Franciszek Stateczny, ur. 1864 w Witosławicach k. Koźla na Śląsku Opolskim. Do Zakonu Braci Mniejszych wstąpił w 1882, pierwsze śluby zakonne złożył w 1885, śluby uroczyste (wieczyste) w 1888 w prowincji weneckiej, święcenia kapłańskie przyjął w 1889. Był wykładowcą dogmatyki w studiu zakonnym w Mantui oraz w Kolegium św. Antoniego w Rzymie (obecnie Uniwersytet Papieski Antonianum), pracował przy krytycznym wydaniu Opera omnia św. Bonawentury w Quaracchi k. Florencji, w Polsce przebywał w klasztorach w Osiecznej, na Goruszkach i we Wronkach. Dnia 1 I 1912 poznańska kuria arcybiskupia mianowała go kapelanem sióstr pasterek na Winiarach pod Poznaniem. Mimo ciągłych podróży i dość niespokojnego 
W 1918 roku, wraz z odzyskaniem przez Polskę niepodległości, zaczęło się odradzać również życie zakonne. Na terenie archidiecezji poznańskiej doczekały tego momentu dwa klasztory franciszkańskie, mianowicie w Miejskiej Górce na tzw. Goruszkach i w Osiecznej koło Leszna. Mieszkało w nich zaledwie sześciu zakonników: trzech kapłanów (o. Antoni Galikowski, o. Nilus Gierszewski i o. Florian Grobelny - ten ostatni przebywał legalnie poza klasztorem i pracował jako wikary w parafii Pępowo koło Gostynia) oraz trzech braci zakonnych. Wymienione klasztory należały do zniesionej w 1875 roku przez zaborców Prowincji Niepokalanego Poczęcia NMP. Władze kościelne i zakonne nie uznały tego aktu bezprawia i prowincja istniała nadal w symbolicznej formie. Zakonnicy prowadzili życie na półkonspiracyjne. Kapłani używali habitu tylko na terenie klasztoru, poza nim chodzili w stroju duchowieństwa diecezjalnego, natomiast bracia niekapłani poza klasztorem używali ubrań cywilnych ${ }^{29}$. Na mocy dekretu generała zakonu Antiqua Ordinis Provincia z 17 marca 1923 roku nastąpiło odrodzenie tej prowincji przez przyłączenie do niej tzw. Komisariatu Zależnego św. Jadwigi na Śląsku, do którego należały klasztory w Panewnikach koło Katowic (obecnie dzielnica Katowic), w Rybniku, Wieluniu i Choczu ${ }^{30}$. Odrodzona prowincja liczyła 64 członków; sześciu pochodziło ze „starej” prowincji, pozostali należeli do Komisariatu św. Jadwigi. Odrodzona prowincja nosiła tytuł Niepokalanego Poczęcia NMP w Wielkopolsce. Po wizytacji generalnej przeprowadzonej przez o. Benedykta Wierciocha, generał zakonu, na prośbę braci, dekretem Sacra visitationis canonica z 6 lipca 1929 roku przywrócił prowincji pełnię praw i przywilejów, a w 1932 roku zmieniono tytuł prowincji na Wniebowzięcia NMP (bez dodatku „w Wiel-

trybu życia pozostawił po sobie bogatą spuściznę pisarską, która obejmuje 135 publikacji. Są to kazania, recenzje książek, modlitewniki, utwory literackie (Stateczny jest uważany za wybitnego przedstawiciela „Młodej Polski” w prozie górnośląskiej), artykuły na tematy społecznie i filozoficzne. Najważniejsze i najwartościowsze są książki: Żywot św. Antoniego z Padwy, Bytom 1912, Żywot św. Franciszka z Asyżu, Poznań 1912 i 1926, Rozbiór krytyczny źródet do żywota św. Franciszka $z$ Asyżu i literatury franciszkańskiej, Poznań 1913, Żywot i pisma Doktora Serafickiego św. Bonawentury, Poznań 1915. Zmarł nagle w Leżajsku 6 III 1921, gdzie zatrzymał się w drodze na Śląsk, aby wziąć udział w plebiscycie. Pochowany tamże. Stownik polskich pisarzy franciszkańskich, Warszawa 1981, s. 457-463.

${ }^{28}$ Antoni Wincenty Galikowski, ur. 1879, do Zakonu Braci Mniejszych wstąpił w 1904, śluby uroczyste (wieczyste) złożył w 1909, święcenia kapłańskie przyjął w 1910 we Lwowie. Po święceniach kapłańskich pracował we Wronkach i Osiecznej. Studiował na uniwersytetach w Berlinie, Wrocławiu i Poznaniu i tam w 1921 uzyskał tytuł doktora filozofii. Od 1923 wykładał w zakonnym studium teologicznym. W 1938 został prowincjałem Prowincji Wniebowzięcia NMP. Autor kilku publikacji popularnonaukowych. Zm. w 1950. Stownik polskich pisarzy franciszkańskich, dz. cyt., s. 137-138.

${ }^{29}$ Tej informacji udzielił autorowi pochodzący z Rawicza ks. Edward Wiśniewski, w latach 70. ubiegłego stulecia proboszcz w Smolicach k. Krotoszyna, który w czasach swojej młodości utrzymywał kontakty z klasztorem na Goruszkach, m.in. z o. Antonim Galikowskim.

30 S.B. Tomczak, Zarys dziejów Prowincji Wniebowzięcia NMP Zakonu Braci Mniejszych w Polsce (1923-1991), [w:] Szkoła Seraficka, nowa seria, nr 1, Katowice-Panewniki 2008, s. 78 i nn. 
kopolsce"), ponieważ w Polsce istniała już prowincja o tej samej nazwie. Była to dawna prowincja bernardyńska $z$ siedzibą prowincjała we Lwowie ${ }^{31}$.

Odrodzona prowincja czuła się na tyle silna, że rozpoczęła starania o objęcie nowych klasztorów. W 1924 roku komisarz prowincjalny, o. Kolumban Sobota $^{32}$, zwrócił się do kardynała Edmunda Dalbora, arcybiskupa gnieźnieńskiego i poznańskiego, prymasa Polski, z prośbą o przekazanie zakonowi klasztoru we Wronkach. Arcybiskup ustosunkował się pozytywnie do tej prośby i pismem z 21 września 1924 roku oddał klasztor franciszkanom z zaleceniem, by urządzili w nim dom rekolekcyjny dla księży i ludzi świeckich. Kilka dni później definitorium prowincji ustaliło skład personalny tej placówki. Stanowiło ją dwóch ojców i dwóch braci zakonnych. Już 17 października 1924 roku przybył do Wronek o. Karol Bik ${ }^{33}$, późniejszy pierwszy przełożony tej placówki zakonnej. Sytuacja, jaką zastał, nie napawała optymizmem, albowiem budynek klasztorny był zajęty przez ludzi świeckich (19 rodzin). Gościny o. Karolowi udzielił na plebanii miejscowy proboszcz. Wbrew wszelkim obawom udało się szybko znaleźć mieszkania dla klasztornych lokatorów i zakonnicy mogli się wprowadzić do swego domu. Uroczyste wprowadzenie franciszkanów do klasztoru wronieckiego odbyło się 26 listopada 1924 roku. Z polecenia władzy kościelnej aktu tego dokonał ks. Włodzimierz Sypniewski, dziekan i proboszcz z Ostroroga. Prowincję reprezentował o. komisarz prowincjalny Kolumban Sobota i o. definitor Ludwik Kasperczyk ${ }^{34}$.

${ }^{31}$ Tamże, s. 78-80.

${ }^{32}$ Kolumban Jan Sobota, ur. 1881 w Gostomi k. Prudnika. Do Zakonu Braci Mniejszych wstąpił w 1901, profesje uroczystą złożył w 1905, święcenia kapłańskie otrzymał w 1907. Był misjonarzem ludowym, gwardianem w Borkach Wielkich, na Górze św. Anny (tam przeżył powstania śląskie, a swoje przeżycia z tego czasu spisał i wydał drukiem), następnie w Panewnikach, Miejskiej Górce, Wronkach, Rybniku. W latach 1923-1926 był komisarzem odrodzonej Prowincji Niepokalanego Poczęcia NMP. Zm. w 1949. S.B. Janicki, Prowincjałowie Prowincji Wniebowzięcia NMP w Polsce w latach 1923-1973, [w:] Szkoła Seraficka, nowa seria, nr 1, Katowice-Panewniki 2008, s. 152-153.

33 Karol Emanuel Bik-Dzieszowski, ur. 1887 w Strzelcach Opolskich, do Zakonu Braci Mniejszych w Prowincji św. Jadwigi wstąpił w 1906, profesję uroczystą złożył w 1910, święcenia kapłańskie przyjął w 1913. Pracował we Wrocławiu i Panewnikach. W czasie plebiscytu śląskiego rozwijał ożywioną działalność na rzecz powrotu Śląska do Macierzy. Za tę patriotyczną postawę otrzymał specjalne podziękowanie i wyrazy uznania od Wojciecha Korfantego. W latach 1928-1939 był proboszczem parafii przy klasztorze w Panewnikach. W tym czasie zainicjował i częściowo doprowadził do końca budowę kalwarii na terenach przyległych do klasztoru. Po wybuchu II wojny światowej przez kilka miesięcy ukrywał się w Krakowie i Zebrzydowicach. Po opuszczeniu kraju przebywał przez pewien czas na Węgrzech, gdzie otaczał opieką duszpasterską Polaków. Po opuszczeniu Węgier był kapelanem żołnierzy polskich we Francji, Belgii i Wielkiej Brytanii. Dosłużył się stopnia kapitana. Zmarł nagle w Newtyle w Szkocji i został pochowany na cmentarzu żołnierzy polskich w Parth k. Edynburga. Autor kilku artykułów o tematyce religijnej i modlitewników. Stownik polskich pisarzy franciszkańskich, dz. cyt., s. 55-56.

${ }^{34}$ Ludwik Jan Kasperczyk, ur. 1885 w Kochłowicach k. Katowic. Do Zakonu Braci Mniejszych wstąpił w 1905, profesję uroczystą złożył w 1909, święcenia kapłańskie otrzymał w 1911. Był nauczycielem w Niższym Seminarium Duchownym w Nysie, rektorem Niższego Seminarium 


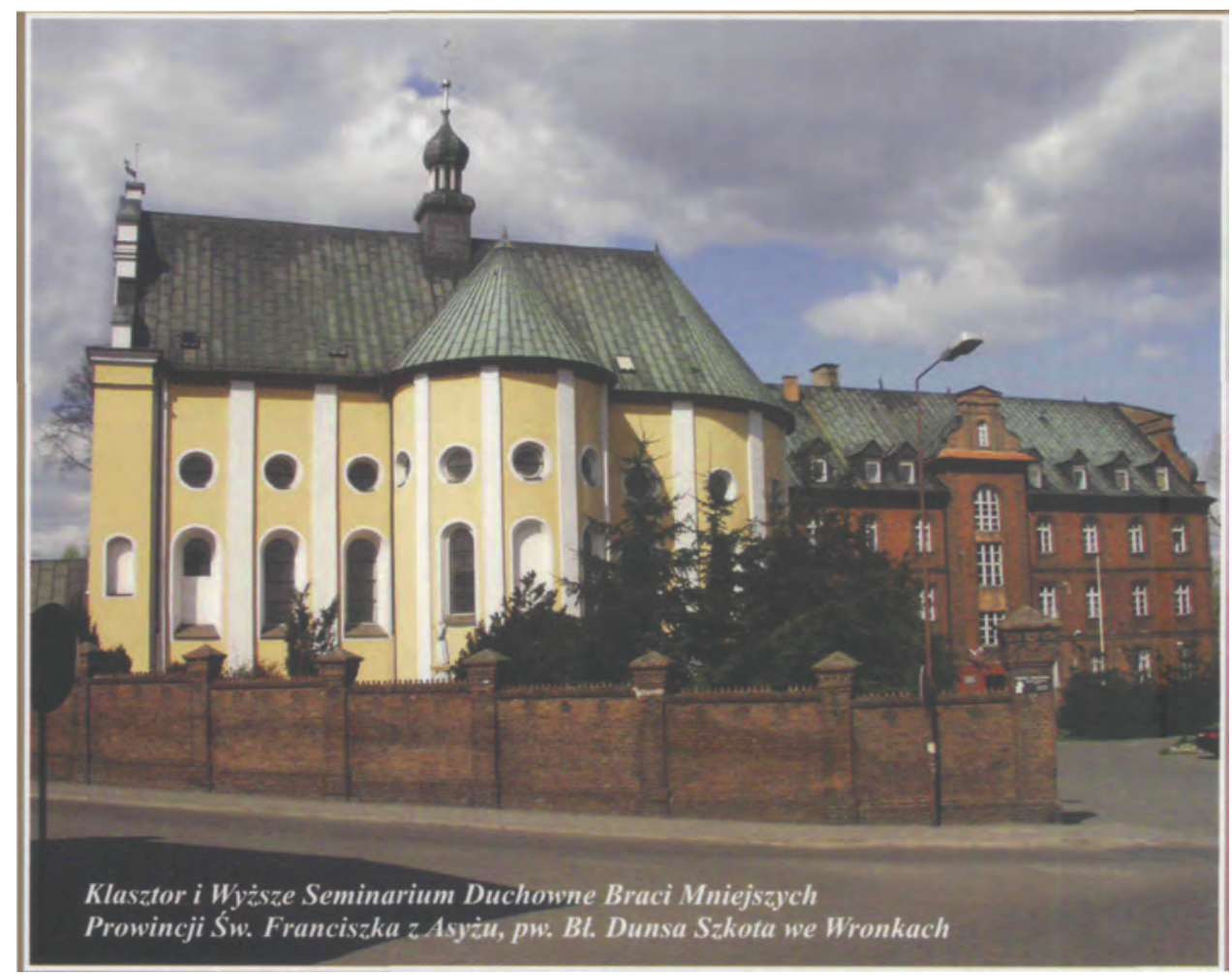

Il. 4. Klasztor we Wronkach - widok współczesny

Franciszkanie z klasztoru wronieckiego oddawali się pracy duszpasterskiej w kościele klasztornym i okolicznych parafiach, głosili rekolekcje i misje ludowe, równocześnie remontowali zespół kościelno-klasztorny. Za zgodą kurii metropolitalnej w Poznaniu urządzono w klasztorze Niższe Seminarium Duchowne, czyli Kolegium Serafickie, które miało kształcić w zakresie szkoły średniej przyszłych kapłanów franciszkańskich. Otwarcie szkoły nastąpiło w 1925 roku. Na początku uczyło się w niej 31 uczniów, w 1930 roku było ich już $50^{35}$. Kolegium Serafickie gościło w klasztorze wronieckim do 1931 roku. Następnie zostało przeniesione do Kobylina, a na jego miejsce zorganizowano studium teologiczne, które było częścią zakonnego seminarium duchownego.

Duchownego w Kobylinie, wykładowcą historii Kościoła i liturgiki w seminarium zakonnym we Wronkach, autor artykułów o tematyce historycznej, które publikował w Szkole Serafickiej, w latach 1929-1931 był prowincjałem. Zmarł w 1949. Slownik polskich pisarzy franciszkańskich, dz. cyt., s. 213.

${ }^{35}$ Katalog Prowincji. 
Działało ono do 1939 roku i wykształciło około 50 kapłanów zakonnych, którzy oddali nieocenione usługi Kościołowi w Polsce.

Klasztor franciszkanów we Wronkach, w znacznym stopniu dzięki mieszczącemu się w jego murach seminarium, był żywym i prężnym ośrodkiem nie tylko życia religijnego, ale także kulturalnego i społecznego, otwarty i wrażliwy nie tylko na potrzeby religijne mieszkańców miasteczka i okolicy. Autor posiada artykuł z prasy przedwojennej pod znamiennym tytułem: Klasztor $i$ więzienie, który ukazuje, czym dla miasta był klasztor wroniecki.

Prawdziwym dobroczyńcą w tym ciężkim czasie stał się we Wronkach klasztor OO. Franciszkanów. Założony już przed „kulturkampfem”, przeszedł w 1924 roku do rąk obecnych właścicieli, którzy dużym wysiłkiem doprowadzili go do należytego stanu... Ojcowie Franciszkanie walczą przy utrzymaniu klasztoru z dużemi trudnościami... Kiedy rozpoczęła się nędza i zawiodły wszelkie sposoby niesienia przez państwo pomocy znajdującym się bez pracy ludziom, wystąpił ze swą pomocą klasztor. Cichą, skromną pracą, nie reklamowaną ani nagradzaną, doszli OO. Franciszkanie do tego, że coraz większemu gronu bezrobotnych mogli przyjść z pomocą materialną, nie mówiąc już o duchowej, której nigdy nie skąpili. Wysiłkiem niewielu ludzi, bo czterech Ojców i dziewięciu Braciszków Zakonnych, utrzymuje się przy życiu i nie złorzeczy na swój los duża gromada ludzi. Klasztor i więzienie. Oba są dzisiaj we Wronkach cichą przystanią, w której ludzie głodni i obdarci są opatrywani. Ale cieszyć się i szczycić może to miasto tylko klasztorem, które swą pracą ułatwia nędzarzom przetrwanie i powstrzymanie ich od wejścia na drogę występku... Klasztor we Wronkach prowadzi zwycięską walkę z nędzą i ratuje ludzi przed zbrodniami...

Seminarium miało także własną orkiestrę, założoną w 1934 roku przez o. Bernarda Jańskiego, do której należeli prawie wszyscy klerycy. Orkiestra występowała na uroczystościach kościelnych i zakonnych (odpust Porcjunkuli, uroczystość św. Franciszka z Asyżu, św. Antoniego z Padwy, Boże Ciało, Boże Narodzenie), a także w czasie świeckich akademii urządzanych z okazji uroczystości państwowych. Orkiestra występowała nie tylko we Wronkach, ale również w okolicznych miasteczkach i wioskach, takich jak Ostroróg, Obrzycko, Biezdrowo i inne. Za pieniądze uzyskane z koncertów (niektóre występy były opłacane) kupowano instrumenty muzyczne, a przede wszystkim spłacono koszta budowy nowego instrumentu organowego w kościele klasztornym; instrument wykonała firma organmistrzowska pana Kaczmarka z Wronek ${ }^{36}$.

${ }^{36}$ Kronika orkiestry 1934-1938 - rękopis bez sygnatury w posiadaniu Centralnej Biblioteki Prowincji św. Franciszka z Asyżu w Poznaniu - wierny odpis wykonany przez członka orkiestry, o. Tymoteusza Frankusa, s. 11. 
Repertuar muzyczny orkiestry był bardzo bogaty i urozmaicony. Przeważały oczywiście utwory religijne, ale sięgano także do tematyki świeckiej, na przykład na akademii urządzonej z okazji 25-lecia kapłaństwa o. Antoniego Galikowskiego, na której był obecny m.in. przyjaciel jubilata, profesor Uniwersytetu Poznańskiego, Michał Sobeski ${ }^{37}$, wykonano uwerturę z opery Wesele Figara. Wykonywano także utwory W.A. Mozarta, F. Händla, F. Schuberta, A. Holzmanna, J. Brahmsa, G. Metella, E. Griega i innych ${ }^{38}$.

Poprzez liczne koncerty orkiestra przyczyniła się nie tylko do uświetniania uroczystości kościelnych, zakonnych i świeckich, ale także do pogłębienia i poszerzenia kultury muzycznej samych kleryków oraz świeckich słuchaczy. Kleryk Stanisław Kałuża dyrygował orkiestrą Korpusu Straży Więziennej. Pod wpływem orkiestry seminarium franciszkańskiego zorganizowali własną orkiestrę klerycy seminarium Księży Misjonarzy Świętej Rodziny w Bąblinie k. Obornik Wielkopolskich ${ }^{39}$.

W czasie II wojny światowej klasztor wroniecki poniósł duże straty materialne i personalne. Niemcy zrabowali dwa dzwony, które zostały wywiezione w głąb Rzeszy i tam przetopione na sprzęt wojenny (czołgu, armaty), zrabowano niektóre naczynia liturgiczne z zakrystii, częściowemu zniszczeniu uległa biblioteka klasztorna i seminaryjna oraz sprzęt domowy. Miejscowi Niemcy zniszczyli dwie figury Matki Bożej z Dzieciątkiem na ręku. Pierwsza z nich stała w pobliżu przystani wioślarskiej nad rzeką Wartą, w otoczeniu bujnej zieleni, druga zaś była usytuowana na wysokiej kolumnie z piaskowca na placu przykościelnym. Zakrystian br. Adjut Kahnert zdjął orła z ołtarza Matki Bożej Częstochowskiej i ukrył go za ołtarzem głównym, przewidując, że Niemcy mogą go zniszczyć. Dzięki temu orzeł ocalał i po wojnie wrócił na swoje miejsce. Również budynki klasztorne i gospodarcze znacznie ucierpiały. W czasie wysadzania mostu na Warcie zniszczeniu uległa część dachu na kościele, Niemcy rozebrali mur łączący plac przed kościołem i ogród klasztorny; w walkach o miasto w 1945 roku radziecki granat spowodował dość dużą wyrwę w budynku klasztornym na pierwszym piętrze ${ }^{40}$.

Niemieckie władze okupacyjne były wrogo nastawione do miejscowych franciszkanów. Od pierwszych dni wojny byli poddawani uciążliwym represjom i restrykcjom. Codziennie dwóch braci musiało się zgłaszać na posterunek policji, gdzie ich następnie trzymano całymi godzinami w charakterze

${ }^{37}$ Michał Sobeski (1877-1939), filozof, działacz kulturalny, krytyk literacki, publicysta, profesor zwyczajny filozofii na Uniwersytecie Poznańskim.

${ }^{38}$ Kronika orkiestry, dz. cyt., s. 15.

${ }^{39}$ Tamże, s. 10.

${ }^{40}$ I. Glensk, Krótka kronika klasztoru oo. Franciszkanów we Wronkach (od najazdu na Polskę w 39 do maja 45), maszynopis w posiadaniu autora artykułu; H. Pieprzyk, Klasztor wroniecki w czasie II wojny światowej 1939-1945, maszynopis w posiadaniu autora artykułu. 
zakładników. Policja raz po raz wpadała do klasztoru na inspekcje, zwłaszcza podziemi kościoła, gdyż tam spodziewano się znaleźć ukrytą broń lub radio, którego posiadanie i słuchanie było stanowczo zakazane. Pomimo tych szykan i niepewności jutra starano się prowadzić w klasztorze normalne życie zakonne. Odbywały się także wykłady dla kleryków. Nie trwało to jednali zbyt długo. Z powodu coraz większego zainteresowania się klasztorem przez gestapo, zwłaszcza klerykami, pod koniec listopada 1939 roku podjęto decyzją o wysłaniu ich do domów rodzinnych, gdzie mieli czekać na dalsze dyspozycje. W klasztorze pozostali: gwardian o. Innocenty Glensk, o. Piotr Szymczak, o. Idzi Tic, br. Adjut Kahnert, zakrystian, i br. Czesław Sobota, krawiec $^{41}$.

Władze hitlerowskie już w październiku 1939 roku wydały pewne restrykcje odnośnie do nabożeństw odprawianych w kościele klasztornym. Samo uczęszczanie do kościoła było przez Niemców uważane za demonstrowanie przywiązania do polskości. Zakazano więc odprawiania codziennych mszy świętych, jedynie w niedzielę można było odprawić dwie msze, o godz. 9 i 11. Poza tymi godzinami kościół musiał być zamknięty. Był stanowczy zakaz odprawiania nabożeństw wieczornych, głoszenia kazań po polsku i śpiewania polskich pieśni, zwłaszcza Boże, coś Polskę $e^{42}$.

Kilku braci ze wspólnoty wronieckiej znalazło się w hitlerowskich obozach koncentracyjnych. Byli to:

1. br. Adjut Kahnert, aresztowany we Wronkach 7 października 1941 roku, przebywał w Forcie VII w Poznaniu i Buchenwaldzie;

2. br. Czesław Sobota, aresztowany we Wronkach 13 sierpnia 1940 roku, przebywał w Forcie VII w Poznaniu i Buchenwaldzie;

3. o. Piotr Szymczak, aresztowany we Wronkach 13 sierpnia 1940 roku, przebywał w Forcie VII w Poznaniu, Buchenwaldzie i Dachau;

4. o. Idzi Tic, aresztowany we Wronkach 13 sierpnia 1940 roku, przebywał w Forcie VII w Poznaniu, Buchenwaldzie i Dachau ${ }^{43}$.

Po usunięciu zakonników Niemcy urządzili w klasztorze szpital wojskowy.

Po zakończeniu działań wojennych franciszkanie w osobach o. Innocentego Glenska i o. Romualda Warzechy wrócili do klasztoru wronieckiego i rozpoczęli odbudowywać życie zakonne i usuwać zniszczenia materialne. $\mathrm{Z}$ ważniejszych dokonań w tym zakresie należy wymienić sprawienie nowych

${ }^{41}$ H. Pieprzyk, Klasztor wroniecki, dz. cyt., s. 3-4.

42 Tamże.

${ }^{43}$ Wykaz na podstawie materiałów zebranych przez o. Edwarda Frankiewicza OFM i o. Hugolina Pieprzyka, które posiada autor artykułu. 
witraży do kościoła (wykonał Stanisław Powalisz), polichromię na sklepieniu świątyni (dzieło Mariana Schwartza ${ }^{44}$ ) i nową posadzkę $e^{45}$.

Przez krótki czas w murach wronieckiego klasztoru funkcjonowało zakonne studium teologiczne. Potem budynek klasztorny zajęło Wojsko Polskie, a po jego odejściu wprowadził się internat dla młodzieży Technikum Spożywczego. Po wybudowaniu internatu na opuszczone miejsce wprowadził się Państwowy Dom Dziecka, który znajdował się tam do 1991 roku $^{46}$.

W związku z utworzeniem w 1991 roku nowej prowincji zakonnej pw. św. Franciszka z Asyżu w klasztorze wronieckim utworzono Wyższe Seminarium Duchowne. Pierwsza inauguracja roku akademickiego miała miejsce we wrześniu 1991 roku. Wyższe Seminarium Duchowne Franciszkanów we Wronkach jest afiliowane do Wydziału Teologicznego Uniwersytetu im. Adama Mickiewicza w Poznaniu ${ }^{47}$.

\section{Ksiądz Wincenty Kałkowski - autor mowy przy pożegnaniu oo. reformatów we Wronkach}

Ksiądz Wincenty Kałkowski był typowym kapłanem społecznikiem wielkopolskim. Urodził się 3 marca 1836 roku w Lusowie, w powiecie szamotulskim, w rodzinie nauczycielskiej, z ojca Walentego i matki z d. Amman. Jego dziadek (ojciec matki) przybył do Poznania jako imigrant ze Szwajcarii, bez znajomości języka polskiego. Stał się Polakiem z wyboru. Polskę szczerze pokochał i tę miłość przekazywał swoim dzieciom. Maturę złożył Wincenty w słynnym poznańskim gimnazjum św. Marii Magdaleny w 1858 roku. Czując powołanie do stanu duchownego, zgłosił się do seminarium duchownego i po studiach w Gnieźnie i Poznaniu w 1861 roku przyjął święcenia kapłańskie. Był wikariuszem w Wyskoci, Inowrocławiu, Ostrorogu i Otorowie. W 1886 został proboszczem w Wilczynie i tam pozostał do śmierci. W swoim życiu kapłańskim pełnił obowiązki wychowawcy młodzieży w Zakładzie ks. Jana Koźmiana w Poznaniu, prezesa Bractwa św. Stanisława zrzeszającego robotników, współpracował z ks. Koźmianem, redaktorem „Przeglądu Poznańskiego” - wtedy ukształtowały się u niego zainteresowanie piśmiennicze. Był wydawcą i nakładcą pisemka religijnego pt. „Posłaniec św. Józefa”. Ten miesięcznik służył pomocą w działalności Bractwa św. Józefa. Czytywany był nie tylko we Wielkopolsce, ale docierał także na Warmię i Śląsk, a nawet do Berlina. Jako proboszcz w Wilczynie

${ }^{44}$ A.M. Wanarska, Święty Franciszek w malarstwie Mariana Schwartza, Wronki 2009, s. 57 (i1.).

${ }^{45}$ Schematyzm Prowincji św. Franciszka z Asyżu Zakonu Braci Mniejszych w Polsce, Poznań 1999, s. 183.

${ }^{46}$ Tamże.

47 Tamże. 


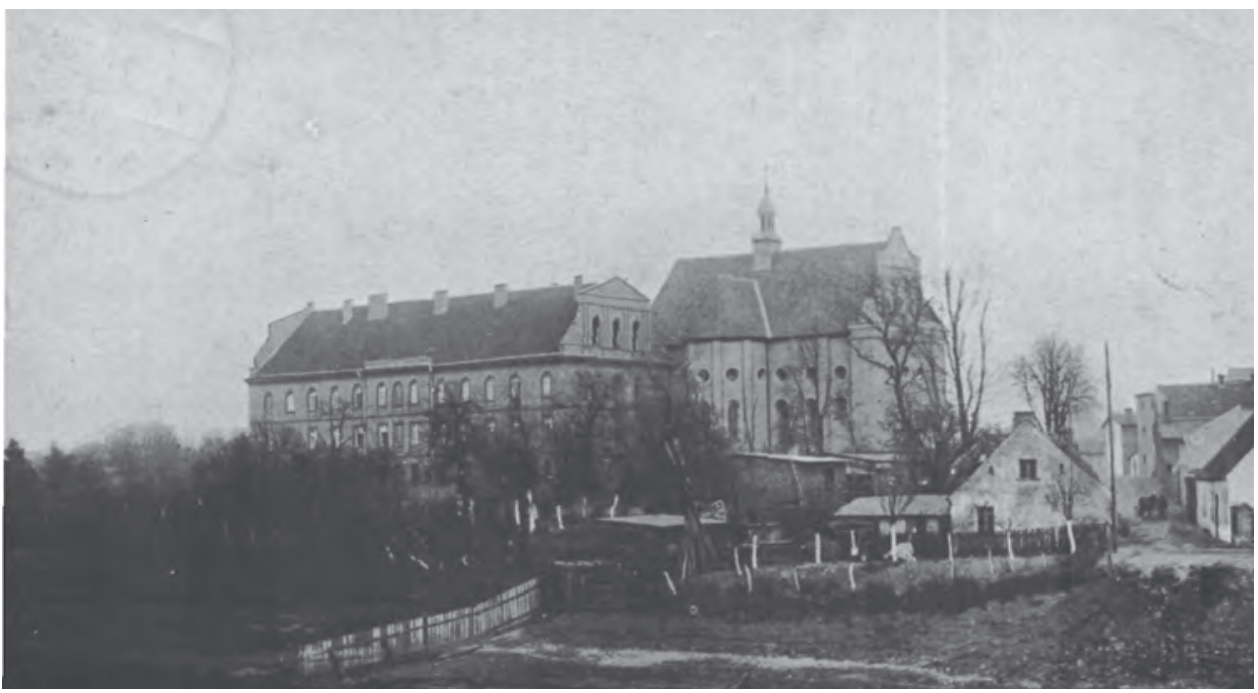

Il. 5. Klasztor we Wronkach, fot. z 1927 r. (Archiwum klasztorne)

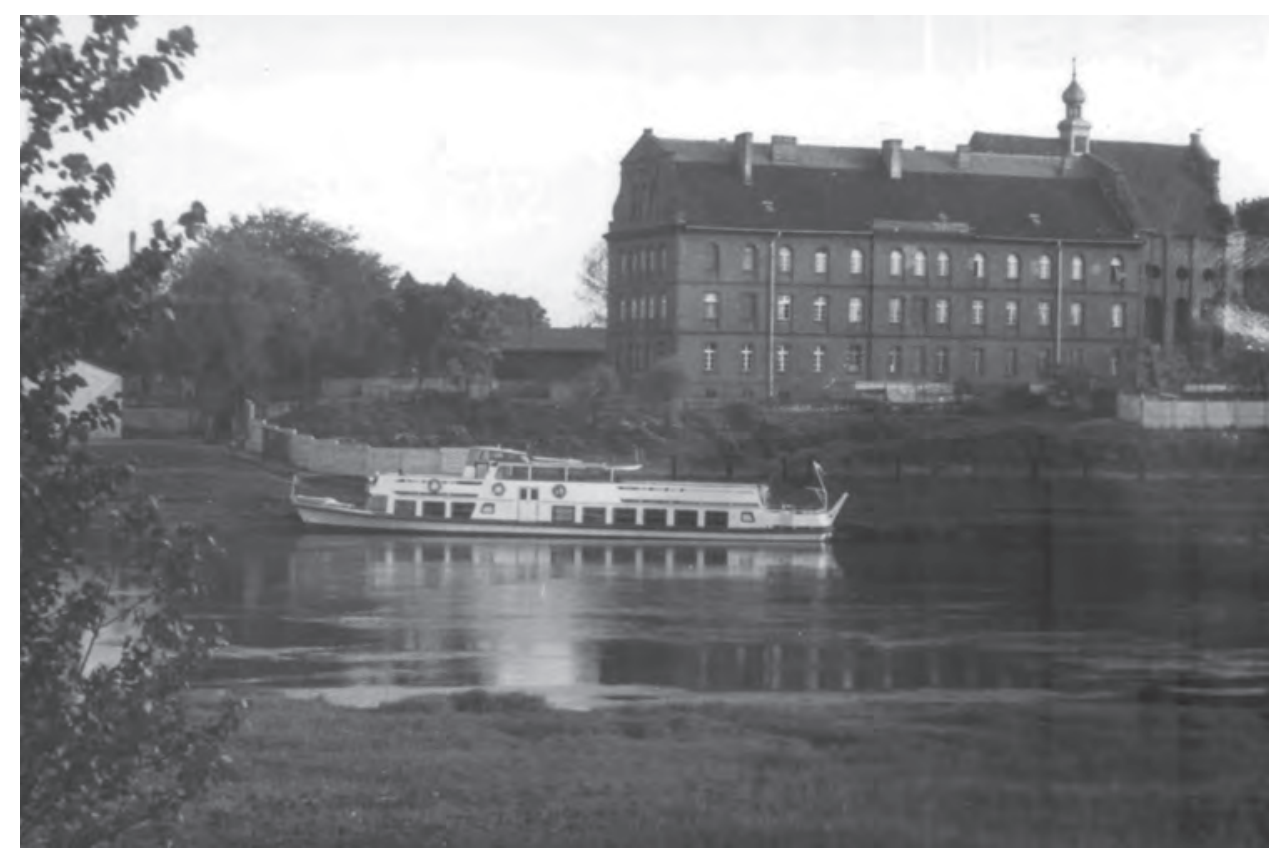

Il. 6. Klasztor we Wronkach, fot. z 1973 r. (Archiwum klasztorne) 
zbudował „wspaniałą, prześliczną jak pieścidełko świątynię”, którą konsekrował w 1895 roku bp Edward Likowski. W trosce o podniesienie życia religijnego i moralnego swoich parafian, urządzał misje i rekolekcje. W 1895 roku założył w swojej parafii Kółko Rolnicze i był jego długoletnim prezesem. Brał czynny udział w pracach Towarzystwa Rolniczego Poznańsko-Szamotulskiego jako jego członek. Był także prezesem diecezjalnym Stowarzyszenia Księży Adoratorów Najświętszego Sakramentu. Zmarł 17 października 1896 roku i został pochowany obok kościoła parafialnego w Wilczynie.

Był autorem licznych artykułów publikowanych na łamach „Posłańca św. Józefa" oraz innych czasopism. Oprócz Mowy przy pożegnaniu wielebnych OO. Reformatów we Wronkach (1875), ukazały się drukiem: Mowa żałobna na cześć śp. Jana Kwileckiego (1882), Nabożeństwo do św. Józefa (1883, wydanie VII 1889) i Godzina adoracji $(1893)^{48}$.

\section{THE FAREWELL SPEECH TO THE REVEREND REFORMED FATHERS IN WRONKI DELIVERED BY PRIEST WINCENTY KAŁKOWSKI. REPRINT OF THE SOURCE AND COMMENT}

\section{Summary}

The monastery in Wronki belongs to the oldest religious foundations in the archdiocese of Poznań. Its long history can be divided into two periods: Dominican and Franciscan. The Dominican period began in 1279 and ended in 1835, when the Prussian authorities canceled religious orders. After the dissolution, it was to be changed into secular purposes and even destructed. In 1854, a Citizens' Committee was established, which decided to save this monument of faith and Polishness. This goal was achieved. In 1868, after purchasing the church and the monastery from private hands, the Citizens' Committee gave the church to the disposal of Gniezno and Mieczysław Hala Ledóchowski, the Archbishop of Poznan, and he gave it to the Franciscans / reformers. The Franciscans only worked in it for 7 years. In 1875, the Prussian authorities closed the monastery and removed the monks. We publish a speech delivered by Fr. Wincenty Kałkowski, vicar from Ostroroga, because of the content contained in it and the great rarity of this print. In 1924, the Franciscans returned to Wronki and in the recovered monastery they organized a lower seminary and in 1931 a theological study. Since 1991, the monastery has been operating the Higher Franciscan Seminary, which is affiliated to the Faculty of Theology of the University of Adam Mickiewicz in Poznan.

${ }^{48}$ Księża społecznicy w Wielkopolsce 1894-1919. Stownik biograficzny, t. II: I-O, Gniezno 2007, s. 79-80. 
Słowa kluczowe: Wronki, klasztor, dominikanie, franciszkanie/reformaci, kasata, mowa pożegnalna, seminarium duchowne, ks. Wincenty Kałkowski, Kulturkampf

Keywords: Wronki, monastery, Dominicans, Franciscans/reformers, dissolution, farewell speech, seminary, priest. Wincenty Kałkowski, Kulturkampf

\section{Bibliografia}

Catalogus Ordinis Fratrum Minorum Provinciae Immaculatae Conceptionis B.V.M. In Polonia Maiore, Mikołów 1930.

Daniluk M., Klausa K., Podręczna encyklopedia instytutów życia konsekrowanego. Pojęcia, terminy, instytucje, dokumenty, czasopisma, sigla, Lublin 1994.

Glensk I., Krótka kronika klasztoru oo. Franciszkanów we Wronkach (od najazdu na Polskę w 39 do maja 45), (maszynopis).

Grot C., Wronki. Z dziejów miasta od czasów najdawniejszych do 1945 roku, Wronki 1987.

Janicki S.B., Prowincjatowie Prowincji Wniebowzięcia NMP $w$ Polsce w latach 1923-1973, w: Szkoła Seraficka, nowa seria, nr 1, Katowice-Panewniki 2008, s. 152-153.

Katalog zabytków sztuki w Polsce, t. V, z. 23, Powiat szamotulski, opr. R. i T. Juraszowie, red. T. Ruszczyńska i A. Sławska, Warszawa 1966.

Kodeks Dyplomatyczny Wielkopolski, t. 1, Poznań 1877.

Kodeks Dyplomatyczny Wielkopolski, t. III, Poznań 1877.

Kozierowski S., Szematyzm historyczny kościołów parafialnych dzisiejszej archidiecezji poznańskiej, Poznań 1935.

„Kronika orkiestry (1934-1938)” - rękopis bez sygnatury w posiadaniu Centralnej Biblioteki Prowincji św. Franciszka z Asyżu w Poznaniu - wierny odpis wykonany przez członka orkiestry, o. Tymoteusza Frankusa.

Księża spotecznicy w Wielkopolsce 1894-1919. Słownik biograficzny, t. II: I-O, Gniezno 2007.

Łukaszewicz J., Krótki opis historyczny kościołów parochialnych ... w dawnej diecezji poznańskiej, t. II, Poznań 1858.

Nitecki P., Biskupi Kościoła w Polsce. Stownik biograficzny, Warszawa 1992.

Nowak P., Dzieje parafii św. Katarzyny Aleksandryjskiej we Wronkach, Poznań 2011.

Pieprzyk H., Klasztor wroniecki w czasie II wojny światowej 1939-1945, (maszynopis).

Piechota W., Czoska F., Zarys dziejów kościoła pod wezwaniem Zwiastowania N.P. Maryi we Wronkach, Wronki 1979 (maszynopis w zbiorach Centralnej Biblioteki Prowincji św. Franciszka z Asyżu w Poznaniu).

Schematyzm Prowincji Wniebowzięcia Najśw. Maryi Panny Zakonu Braci Mniejszych w Polsce, Katowice 1989.

Schematyzm Prowincji św. Franciszka z Asyżu Zakonu Braci Mniejszych w Polsce, Poznań 1999.

Stownik polskich pisarzy franciszkańskich, Warszawa 1981.

Tomczak S., Dzieje kościoła i klasztoru franciszkanów we Wronkach, „Wronieckie Sprawy”, R. 2, nr 8 (11) listopad 1991.

Tomczak S., Arcybiskup Leon Przyłuski i odrodzenie franciszkanów-reformatów w Wielkim Księstwie Poznańskim, „Poznańskie Studia Teologiczne”, t. 2 (1978), s. 305-318.

Tomczak S., Zarys dziejów Prowincji Wniebowzięcia NMP Zakonu Braci Mniejszych w Polsce (1923-1991), w: Szkoła Seraficka, nowa seria, nr 1, Katowice-Panewniki 2008, s. 78 i nn.

„Tygodnik Katolicki” (Grodzisk), nr 36 (1868), s. 380.

Wanarska A.M., Święty Franciszek w malarstwie Mariana Schwartza, Wronki 2009.

Wielkopolski stownik biograficzny, Warszawa-Poznań 1981.

Wiesiołowski J., Dominikanie w miastach wielkopolskich w okresie średniowiecza, [w:] Studia nad historia dominikanów w Polsce 1222-1972, t. 1, Warszawa 1975, s. 204. 
M O W A

PRZY POŻEGNANIU

WIRUBRIYCH OO. RPRORMATÓW

WE WRONKACH

POWIEDZIANA

PRZEZ

X. IKA LKOWSKIEGO WIKARYUSZA W OSTROROGU.

하요용

\section{POZNAŃ.}

N A K L A D E M A U T O R A.

1875 . 


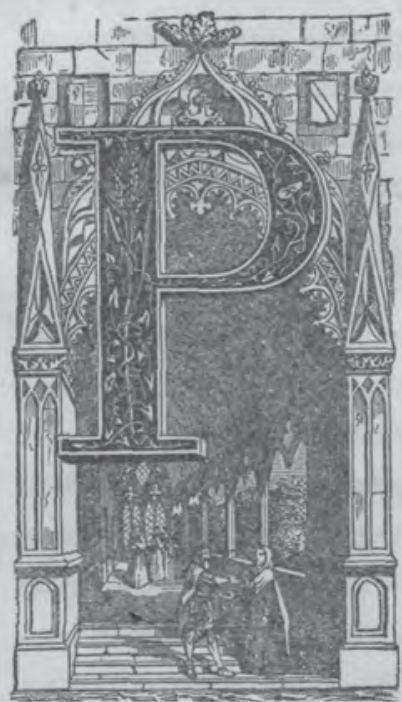

Jajmilsi!

ewno nie bez rozrzewnienia stawacie dzisiaj w téj świątyni - wszak żeź po raz ostatni śpievvają w niéj Synowie Sw. Franciszka chwałę boźą; nie bez wzruszenia wstępuję i ja na to miejsce święte; smutny albowiem, Czcigodni Ojcowie, przyjąłem na siebie obowiązek poźegnania Was w imieniu okolicy, w imieniu zgromadzonego ludu i w mojem vłasnem imieniu. Przez lat siedm patrzała okolica bilższa i dalsza na chwalebną Waszą gorliwośc, przez lat kilka furta Wronieckiego Zgromadzenia gościnnie i serdecznie przedemną się roztwierała; nic przeto dziwnego, iż ubytek Wasz w tkliwą serca naszego uderza strunę. Za chwil kilka zamilknie dzwonek klasztorny kto wie czy nie na zawsze? - i nie będzie Was więcéj zgromadzał do wspólnéj modlitwy za bracią w śviecie 
4

żyjącą; rozejdziecie się pewnie wszyscy na cztery wiatry, na ulicach Wronieckich nie ukaże się więcéj Wasz - pokorę i ubóstwo - te dwie najpiękniejsze cnoty - opowiadający habit, ani poniesiecie błogosławieństwo w dom, który przed Wami nie zamykał serca, ni dłoni kurczył. Bądżcie jednakowoż przekonani, iż Wasz sandał, Wasz kaptur mniszy, i Wy sami po długie czasy w sercu naszem, w pamięci naszéj źyć będziecie.

Najmilsi ! aby dokładnie ocenić, ile to rzeczywiscie w obecnéj chwili z dopuszczenia Bożego tracimy - dzisiaj kiedy oto Wielebni O. O. Reformaci z przed oczu naszych się usuvają, wskażę Wam po krótce: jakie w ogóle zasługi Synowie Świętego Franciszka dla Kościoła, dla narodu a szczegółowo dla Wronek położyli.

Zakon Świętego Franciszka zapełnia jednę z najpiękniejszych kart historyi Kościoła. Okoliczności, w których wielki ten Święty za natchnieniem Nieba w ogrodzie bożym, to jest w Kościele Świętym śliczne drzewvko swojéj reguły zasadził, drzewvo, które się póżniéj w tak silny i ani czasem ani żadną burzą niezłamany dąb rozrosło, - okolicznosci powtarzam ówczesne, z wielu miar z naszemi, w których źyjemy, porównać zupełnie sprawiedliwie można. Na ołtarzu ogólnéj czci stał jak i dzisiaj cielec złoty; a kto raz temu boźyszczowi ziarnko kadzidła na ofiarę rzucił, w czyjem sercu miłość złotéj gliny swoje zapusciła korzenie, juź nie łacno pokłoni się szczerze ubogiemu Bogu, składającemu swe drobne ciałeczko nasamprzód w kamiennym żłobie, a późniéj nagiemu na Krzyźu. Miłość ta nierządna zapełnia serce nasze jeno liczbami, miarą i wagą kupiecka - i niweczy w nas tak często najgodziwsze i najświętsze uczucia przyrodzone, targa najsilniejsze bo rodzime vvęzły, jak to w historyi Świętego Franciszka jasno widzimy. Według tejże historyi wypiera się ojciec rodzonego 
5

syna. I dla czego? Czyli syn Franciszek jakiejkolwiek dopuscił się zbrodni? Najmilsi! wór pokutniczy i powróz, którym się przepasał, otóź cała zbrodnia i vvina Franciszka Svviętego, ta jedyna zbrodnia zamieniła ojca w okrutnika. A kto tak skąpo miał serca dla krwi swojéj własnéj, czyli mniemacie, iźby chętniéj przytulił do siebie człowieka obcego? Ojciec niechce widzieć syna, poniewaź nędzną odziany szatą, jakżeź, czyliż czułe rzucicie spojrzenie na żebraka odartego, z którym go żadne nie łączą węzły, względem którego żadnych na siebie nie zaciągnął obowiązków? W mniemaniu człowieka takiego czemżeż jest ubogi? Oto wołem, który na pana ciężko pracuje i wielbłądem, który skarby pańskie dźwiga.

Wiek XII., wiek, w którym się Swięty Franciszek urodził i działał, bardzo obfitował w ludzi podobnego usposobienia. - Jakiegoż przeto szacunku i jakiéj czci godzien mąź, który tak przewrotną na wskroś ideę zaczepił odwaźnie, a w miejsce jéj inną chrzesciańską zaszczepił i przeprowadził, który śmiało wszystkim mówił: bogaczu podaremnie się chlubisz złotem i srebrem, fwoje skarby rzetelnéj nie posiadają wartosci, twoje skapby niesprawiedliwie w społeczeństwie ludzkiem na wyższem sadzają cię stanowisku, niesprawiedlidlivie nadają ci prawo lekcevvażenia tymi wszystkimi, którzy szczuplejszy blask bogactwa w około siebie roztaczają, - jakiegoż powtarzam godzien szacunku mąż, który suknią swoję ubogą w krwawym pocie uczciwie zapracowaną wysoko w społeczeństwie podniósł, a nawet nad szatę złocistą, chociaź jako syn bogatego kupca łacno się mógł w niéj pysznić, przeniósł? Mąż zaiste taki nietylko wielkim jest. w Kosciele, nie, - eałe społeczeństwo ludzkie jemu pomnik wielkosci postawić powinno. -

Prawda, juź przed Świętym Franciszkiem wielu widzimy założycieli zakonów - światłych nauką, pilnych w modli- 


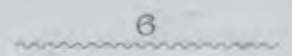

twie, gorliwych o chwałę bożą, atoli żaden z nich ideí ubóstwa na tak szezytnem nie postawił stanowisku jak Swięty Franciszek, żaden przeto także z nich ogółowi ludzkiemu, który, jak widzicie, po największéj częsci z ubogich się składa, tyle się nie przysłuźył, ile właśnie Franciszek Swięty.

I niebu całemu myśl i praca naszego Śviętego bardzo się spodobały, o czem was niezwłocznie, Zgromadzeni w Chrystusie, $z$ historyi przelronam. Panował na ówczas na stolicy Piotrowéj Innocenty III, jeden z najznakomitszych papieży. Papież ten na bardzo rozsądnych opierając się pobudkach, postanowił żadnego nowvego nie potwierdzaé zakonu. Kiedy przeto Franciszek Święty regułę swoją Stolicy Apostolskiéj do potwierdzenia przedłoźył odmowną początkowo odebrał odpowiedż. I dokądże udasz się teraz Swięty żebraku z twojemi świętemi planami i przedsięwzięciami? Ojciec jeden juź się Ciebie zaparł, ojciec drugi, ojciec całego swiata katolickiego odmawia błogosławieństwa na świętą pracę twoją, a gdzie Kościół śvięty swego nie złoźy krzyżyka - tam i rosa z nieba oźywiająca t. j. łaska swięta zwykle nie spływa. Nie zraziła atoli bynajmniéj Franciszka Swiętego odmowna odpowiedź Innocentego; wiedział albowiem dobrze, że każda sprawa dobra wszystkie próby ognia przejść musi, wiedział dobrze, że każdéj myśli i pracy świętéj nietylko żli ale z dopuszezenia Boźego nawet i sprawiedliwi początkowo opór stawiają. - Wszakżesz powiada Pismo Śvięte, że kiedy Pan Jezus o najpiękniejszéj tajemnicy swojéj miłości, t. j. o Najśviętszym Sakramencie Ołtarza mówił, to nie tylko Faryzeuszovvie $\mathrm{i}$ inni nieprzyjaciele Chrystusa Pana, nie - ale sami Apostołowie, ci najwierniejsi przyjaciele Jego, z tych słóv tak pełnych pociechy się gorszyli.

Sprawa jednakże dobra ostatecznie zawsze zwycięża. Swiętego Franciszka sprawa, który jeno za wyższem na- 


\section{- 7}

tchnieniem Bożéj jął się pracy, także w końcu zvvyciężyła. Innocenty III. widzi we snie kosciół Lateraneński w Rzymie, najstarszy w świecie katolickim, chylący się ku upadkowi, a oto mąź ubogi, w którym Franciszka Świętego poznaje, podpiera go i od ruiny chröni. W pięknym tymalegorycznym śnie poznaje papieź palee Boźy; za radą zatem kardynałów, bez wahania regułę Franciszka Świętego zatwierdza.

Czasy następne okazały, jak wielkie korzysci Kosciołowi Swiętemu reguła ta przyniosła. Winnica Pańska zyskała w Synach Świętego Franciszka gorliwych pracowników. Jak ziemia daleka i szeroka, wszędzie ujrzeć byście mogli brunatny habit - wszędy Synowvie tego Świętego Wielkiego opowiadają Ewangelią, a ani głód, ani nawet śmierć pohamować ich chwalebnéj gorliwóści nie umieją.

Któż zaś policzyć zdoła Śviętych Męczenników, Śvięte Panny i Wdowy, Swiętych Wyznawców wszelakiego stanu i rodzaju, jakimi zakon Swiętego Franciszka niebo zapelnił? I Polska nasza ma tam także swoich zastępców, którzy wv tym zakonie siebie uświęcili i zbawili jak n. p. Jana Kapistrana, błogosławioną Jolantę, ciało jéj aż dotąd w Gnieźnie spoczywa, i wielu innych. A i dzisiaj jeszeze wiele dusz sprawiedliwych, my ich prawda nie znamy, ale niebo całe $\mathrm{z}$ upodobaniem na nie z góry spogląda, według reguły Śviętego Franciszka źycie swoje urządza, wspomnę tu tylko śviątobliwego Drukteina Polaka, który kilka lat temu w Rzymie w pocałunku Pana zasnął.

Zakon ten przeto juź jako własnosć ogółu naszéj czci jest godzien, a cóż dopiero, jeżeli rozwaźymy szczegółowo jego zasługi względem narodu naszego, czyliź ta cześ́ nie będzie szczerszą i wyźszą? Zapewne! Polska nasza, Zgromadzeni w Chrystusie, gościnnie u siebie przyjmovvała każde zgroma- 
dzenie religijne; śmiało powiedzieć mogę, iż wv Kościele boźym prawie żadnego nie znam zakonu, któryby ziarnka swego na polskiéj, żyznéj nie był siał niwie, ale z tych wszystkich zakonóv i zgromadzeń znowu nie znam żadnego, i to takźe \$miało mówię, któryby się tak ściśle był zrósł z historyą naszą, jak właśnie Świętego Franciszka zakon. Dziecko to z pod ciepłego bo włoskiego nieba nie zmarzło przy ogniu polskich serc, i owszem ze wszystkich swoich rówienników ono na polskiéj ziemi najwięcéj się rozrosło i zmężniało. Przejdźcie całą ziemię polską wszerz i wzdłuż, a nie znajdziecie, dosłownie nie znajdziecie żadnego miasta lub miasteczka większego, kędyby mury klasztorne po zakonnikach reguły Swiętego Franciszka nie swiadczyły o prawdzie tego - com dopiero Wam powiedział. Tak jest, ze wszystkich zakonóv, zakon tego śviętego Patryarchy najsilniejsza, stanowił falangę. I to nie bez przyczyny. Kiedy albowiem inne zgromadzenia zakonne miały na celu albo osobiste uśvięcenie przez kontemplacyą, albo ukształcenie $i$ uświęcenie mianowicie pojedyńczéj vvarstwy społeczeństwa naszego, to klasztor Franciszkański stał się, o ile mógł i umiał, za przykładem Świętego Pavvła wszystkiem dla wszystkich. I dla tego to Polska także temu szczególniéj zakonowi na schronienie najwięcéj postawiła muróv.

Mury te drogiemi powinny być sereu naszemu; bo to śviadectwo poboźnosci Ojeów, a co więcéj, w nich się zamyka przeszłosé nasza, - to świadkowie naszych tryumfów i zawodów. Ilekroé razy na mury podobne spojrzę, przed oczyma memi całe dzieje ojczyzny mojéj się snują. Sklepy ich? to jeden wielki cmentarz! Tam Polska całą swą wielkość chowvała! - Tu widzę szezątki infuły biskupiéj; - kto wie, czy nie zdobiła niegdyś Prymasa, gdy w Krakowie kładł na głowę któremu z królów naszych koronę panowania ziemskiego; - tam znowu niedopruchniały szmat żupana - to moźe Senator, który o dobru rzeczypospolitéj mądrze radził, tutaj 


\section{9}

spoczyvva; - gdzieindziéj potrącam o zardzewiałe szczątki karabeli, pewnie z pod Wiednia pamiątka; - może jaki Hetman lub inny rycerz waleczny broniąc Europy przed Islamizmem, topił ją w krwi pohańca Turka.

I znowu widze, jak oto po kurytarzach klasztornych wojskowa się wije druźyna. W obszernym refektarzu zasiadł za stołem Hetman w boju posivviały - w około niego dzielni wodzowie. U wszystkich wąs sumiasty, czupryna podgolona - silna pięsé i silna wola. Na twarzach powaga i stanowczosć rozlana, oko ogniem się źarzy. Snać coś waźnego uradzili, - na wojenkę pójdą. Ale wprzódy kaźdy z nich przed najstarszym i najdośviadezeńszym definitorem, - który mało mówi, a tak wiele się modli, złoźy brzemię grzechów; bo to na wojnie nikt nie pevvien źycia swego, a Pan Bóg czystemu sercu jakoś więcéj błogosławi i vvięcéj dodaje odvvagi. - Nazajutrz Msza uroczysta; wszyscy kolejno do Ottarza przystępują, Ciało Boźe przyjmują. Po skończonem nabożeństwie krótkie śniadanie. Juź trąbka dzwoni wojenna, - juź na koń wsiedli; Ojeiec Prowvincyał chorągiew Boga Rodzicy święci, krzyż święty nad całym pułkiem czyni, - marsz - marsz, i już zniknęli. Szczęsé Wam Boże na dóbrą sprawę! I cicho znowu w samotnym klasztorze, w miejsce gwvaru wojskovego monotonne echo modlitwy zakonnéj słychać. Mój Boże, vwsystko to było, - dziś zostało upomnienie.

Najmilsi, Synowie Śviętego Franciszka nie tylko goscinnie roztwierali furtę swą na przyjęcie walecznych synów Ojczyzny, - nie - lecz takźe osobiscie i czynnie na ołtarzu jéj swoje składali daniny. Pamiętacie dobrze rok 1883. Nie zbrodnia, ale śvięta miłośé kochanéj Ojezyzny wystawiła vó́wczas nie jedną szubienicę, a czy już wygasł w pamięci Waszéj ów habit brunatny, - który także na stryczku zawisł, i tym sposobem w obec swviata chlubne złożył śviadectwo, że 
10

w Polsce nie tylko śviecey, ale i zakonni, nigdy przed najdroższą nawet nie wzdrygali się dla swojéj Ojczyzny ofiarą? I w zimnych lochach Sybiru znalazłbym niejednego szlachetnego niewolnika; dzisiaj do taczek przykuty, - w łachman ustrojony. Dla czego cierpi? Jakiejżeż zbrodni vvinien? Otóź pod grubym i twardym habitem zachował serce czułe, które pięknie bić umiało miłością Ojczyźny, a dzis róvvnież pięknie dla niéj cierpieć umie.

I pod względem naukowym OO. Reformaci niemałe dla kraju połoźyli zasługi. Nie mieli oni wprawdzie szkół vviele jak Jezuici i Piarzy, chociaż i takie były n. p. w Pakosei koło Inowrocławvia, to prawda; ale natomiast każdy z Ojeów téj reguły pięknéj w chwilach wolnych od pracy i posługi duchownéj gromadził około siebie młódź polską i uczył ją nie tylko odmawiania koronki ale i łaciny z Alwara, a przykładami dawnych wodzów znakomitych zaszczepiał w niéj odwagę i męztwo. Gdybym policzył wszystkie sivve głowy naszych nestorów, przed którymi każdy z nas pod kaźdym względem chętnie swoje schyla czoło - i gdybym ich zapytał, kędy się nauczyli byé poboźnymi, rostropnymi, wielkimi? zaiste bardzoby wielu wyznało, że w skromnych murach Reformackich na łavvie szkólnéj, pierwsze svvojéj wielkości załoźyli fundamenta.

Pozostaje mi jeszcze wykazać zasługi Wielebnych 0 . Reformatów, jakie szezegółowo dla Wronek połoźyli. Najwięcéj i najpiękniéj o tym punkcie winienem włascivvie i umiem powiedzieć. Darujeieź jednakowoż, iź się najskromniéj wyrażę; nie cheę alboviem więcéj rozezulać juź $i$ tak bardzo rozrzewnionych serc Waszych. Krótko powiem: Czcigodni oo. Reformaci Wronki bardzo wysoko podniesli. Tak pod względem materyalnym jak téź i duchovvym, miasto, tutejsze bardzo Im zaiste wiele zawdzięcza. Nie przynieśli ze sobą 
ani złota, ani innych skarbów; a jednakowoź źaden by i najbogatszy bankier lub filozof najmędrszy nie byłby tyle zdziałał, ile Czcigodni Ojcowvie Reformaci rzeczyviscie dla Was zdziałali.

Nad Wartą, - gdzie się dzisiaj piękna swiętynia wraz ze wspaniałym klasztorem i obszernym ogrodem vznosi, - cóżeście tam lat temu siedm vidzieli? Ruinę i miejsce śmiecisk. Otóź pracowita ręka zakonnika na miejscu zgnielizny novve zaszczepiła życie i miastu piękności znacznie przyczynié umiała. Ileż to dobrodziejstw $z$ tych pięknych murów nie spływało na mieszkańców Wronieckich? Nietylko, że ubodzy nigdy podaremnie do zakonnéj nie zakołatali furty, ale przez częste odpusta, które z daleka licznych ściągały pielgrzymóv, mianowicie stan kupiecki znaczne odniósł korzýści. Ztąd także nad ubytkiem -Wielebnych OO. Reformatów nie tylko katolicy, ale także innowiercy i źydzi, - kaźdy z innych pobudek, - ubolewają. - A kto policzy sumienia w Ich pięknym kościele ezyszczone, cnoty zaszczepione i pielęgnowane? Chyba na sądzie Boga przed oczyma naszemi to wszystko się odsłoni. I cóź Wam damy Wielebni OO. Reformaci przy poźegnaniu na upominek za tak wiele dobrodziejstw? Tyle żescie zdziałali pięknego, iż rzeczywiście nie stanie nas na dar odpowiedni: Przyjmijeie przeto krótkie a serdeczne Bóg zapłaé: Bog zapłaé w imieniu okolicy, - Bóg zapłać w imieniu miasta - Bóg zapłaé wv imieniu mojem. Juź policzone godziny Waszego pobytu w pośród nas - opuścicie nas; droga klasztorna stopą poboźnego pielgrzyma vydeptana pewnie nie długo trawą zarosnie, droga jednakowoż, którążeście sobie przez serce nasze wydeptać umieli, chwastem zapomnienia nie zarośnie nigdy. Zamilknie organ w Świątyni Waszéj i nie będzie więcéj wygrywvał: "Lulajże lulaj Jezuniu kochany," .. albo "Wesoły nam dzień dziś nastał," i t. p.; w pamięci atoli poboźnego ludu nie przebrzmi piękna muzyka Evvangielii, 


\section{2}

którążeście opowiadali i wykładali. Idżcieź więc juź z Bogiem, - a czy to pod gorącem słońcem innéj półkuli ziemi, lub gdziekolwiek indziéj, - w miłéj nas zawsze zachowajcie pamięci.

A teraz Czcigodny Celebransie, osobisty mój przyjacielu, Ojcze Wincenty, pozwól, że do Ciebie szczegółowo kilka słów pożegnalnych zwrócę.

Z Wronieckiego Zgromadzenia Ty najpierwszy na niepewne puszczasz się morze, aźeby w pośród obcych szukać schronienia. Ze wszystkich Ojców najdłuźéj w tutejszym klasztorze pracowałes, a więc szlachetna Twa ręka do pięknéj budowy materyalnéj i duchowéj we Wronkach pewnie najwięcéj cegiełek złożyła. Dzisiaj po raz ostatni składasz w téj Świątyni uroczyście Przenajświętszą Ofiarę, i moźesz powiedzieć to, co niegdyś Paweł Święty przy swojem pożegnaniu w Milecie wyrzekł: „Juź mnie więcéj nie zobaczycie.“ Zaiste smutek nie mały na to wspomnienie serca nasze ogarnia; tracimy albowiem w Tobie bardzo wiele. Tracą grzesznicy ojca wyrozumiałego - lud wierny traci dobrego kaznodziejęa wielu z nas przyjaciela, którego miejsce nie tak łatwo kto inny zastąpi. Bądź zdrów ! Aniół Stróż niechaj Cię zaprowadzi na miejsce przeznaczenia, a Pan Bóg łaskawy jeżeli nie gdzieindziéj - to przynajmniéj w niebieskiem niech nam pozwoli zobaczyć się Jeruzalem. Amen. 